\title{
Reviewing the Antioquia batholith and satellite bodies: a record of Late Cretaceous to Eocene syn- to post-collisional arc magmatism in the Central Cordillera of Colombia
}

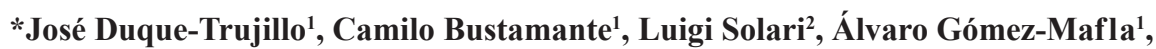 \\ Gloria Toro-Villegas ${ }^{1}$, Susana Hoyos ${ }^{1}$ \\ I Departamento de Ciencias de la Tierra, Universidad EAFIT, Carrera 49 No. 7 sur-50, Medellín, Colombia. \\ jduquetr@eafit.edu.co,cbustam3@eafit.edu.co,agomezm@eafit.edu.co,gtoro@eafit.edu.co,shoyosm1@eafit.edu.co \\ 2 Universidad Nacional Autónoma de México, Centro de Geociencias, Campus Juriquilla, Blvd. Juriquilla No. 3001, 76230, Querétaro, México. \\ solari@unam.mx \\ *Corresponding author: jduquetr@eafit.edu.co
}

\begin{abstract}
The Antioquia batholith represents the magmatic record of the interaction between the Farallón and Caribbean plates with the NW part of the South American Plate during the Meso-Cenozoic. Several authors have reported zircon U-Pb ages and whole rock geochemistry in order to constrain the crystallization history of this batholith and its formation conditions. The present work aims to gather the existing data with new data obtained from the Ovejas batholith and La Unión stock, both genetically related to the main intrusion. Gathering our new data with information obtained in previous works, we conclude that the Antioquia batholith was constructed by successive pulses from $c a$. 97 to $58 \mathrm{Ma}$ in an arc-related setting. The initial pulses are related to syn-collisional tectonics, during the early interaction between the Farallón plate and NW South America. The final pulses, that record Eocene ages, are related to a post-collisional setting, similar to that recorded in other plutons of the Paleogene magmatic arc of the Central Cordillera.
\end{abstract}

Keywords: Antioquia Batholith, Magmatism, Central Cordillera, Colombia.

RESUMEN. Revisión sobre el Batolito Antioqueño y sus cuerpos satélites: registro del magmatismo syn- a poscolisional entre el Cretácico tardío y Eoceno en la cordillera Central de Colombia. El Batolito Antioqueño representa el registro magmático de la interacción entre las placas Farallón y Caribe con la parte NW de la placa Sudamericana durante el Meso-Cenozoico. Varios autores han obtenido edades U-Pb en circón y geoquímica de roca total con el objetivo de definir el ambiente de formación y la historia magmática de este importante cuerpo intrusivo. El presente trabajo pretende reunir los datos hasta ahora existentes junto con nuevos datos sobre los cuerpos satélites de Ovejas y La Unión, ambos relacionados genéticamente con la masa principal del batolito. De esta compilación, concluimos que el Batolito Antioqueño fue formado por una serie de pulsos magmáticos entre $\sim 97$ y $58 \mathrm{Ma}$ en un ambiente de arco magmático. Las fases iniciales de este magmatismo corresponden a un ambiente tectónico syn-colisional correspondiente a las fases iniciales de la interacción entre las placa Farallón y NW de la placa Sudamericana. Mientras que las fases finales, de edad eoceno, se relacionan con un ambiente poscolisional, similar al registrado en otros plutones del arco magmático Paleógeno de la cordillera Central en Colombia. 


\section{Introduction}

Granite batholiths are found in continental magmatic arcs around the world and constitute the main vestiges of subduction-related settings (Best, 2013). These are constructed over time spans from $10^{5}$ to $10^{6}$ years by the incremental assembly of small magma batches (Coleman et al., 2004; Annen et al., 2015).

In that sense, they can record significant changes in the tectonic style of convergent margins through time, identified when U-Pb geochronology in zircons and whole rock geochemistry is combined and its spatial distribution is considered. The whole Andean chain includes several Meso-Cenozoic granitoids that record the continuous subduction setting that has molded the western margin of South America since the breakup of Pangea during the Triassic (Ramos, 2009; Ramos and Aleman, 2000). Hence, studying these granitoids may help to unravel evolution of the continental margin.

A major arc-continent collisional event took place in the western margin of northern South America related to its interaction with the Caribbean Large Igneous Province during Late Cretaceous (Cardona et al., 2011; Villagómez et al., 2011; Bayona et al., 2012; Spikings et al., 2015; Jaramillo et al., 2017). A contemporaneous granitic magmatism appeared in the Central Cordillera represented by the intrusion of the Antioquia batholith, a granodiorite to tonalite pluton formed by multiple pulses from ca. 90 to $60 \mathrm{Ma}$ (Ibáñez-Mejía et al., 2007; RestrepoMoreno et al., 2009; Ordóñez and Pimentel, 2001; Ordóñez-Carmona et al., 2006; Leal-Mejía, 2011; Villagómez et al., 2011). This was succeeded by a Paleogene post-collisional magmatic arc which includes the Eocene portion of the Antioquia batholith (Leal-Mejía, 2011; Bayona et al., 2012; Bustamante et al., 2017). The later suggests that the continental margin was subjected to a progressive thickening since its interaction with the Farallón plate, and that may be recorded by the Antioquia batholith.

However, geochemical and geochronological data from this batholith are limited to scarce international works presenting extensive formation ages and discussing the origin of the Antioquia Batholith in a long term tectonic model including both the transition from Nazca-dominated to Caribbeandominated tectonics.
In this paper, we present new U-Pb crystallization ages from one of the earliest (La Unión stock) and intermediate (Ovejas batholith) pulses of the Antioquia batholith, and also provide new whole rock geochemistry. This information combined with a compilation of available data obtained from previous works, will allow us to outline the crystallization history of the Antioquia batholith in relation with the Meso-Cenozoic subduction setting of the NW corner of the South American Plate, tracking the thickening that experienced the margin during the Late Cretaceous and lasted until the Eocene.

\section{Geological setting}

Three N-NE trending Cordilleras built the Andes of Colombia. The Eastern Cordillera, mainly constituted by a Proterozoic metamorphic basement covered by highly deformed Paleozoic to Cenozoic sedimentary sequences (Villamil, 1999; Sarmiento-Rojas et al., 2006). This cordillera is separated from the Central Cordillera by the Magdalena River Valley, which in turn consists of Permo-Triassic gneisses, migmatites and amphibolites (Martens et al., 2014) and Jurassic schists belts (Blanco-Quintero et al., 2014; Bustamante et al., 2017) intruded by Jurassic (Cochrane et al., 2014; Bustamante et al., 2016) and Cretaceous to Paleogene arc-related plutons respectively (Bayona et al., 2012; Bustamante et al., 2017). The northernmost exposure of the latter magmatic belt continues under the Lower Magdalena Valley, represented by the Bonga pluton (Mora-Bohórquez et al., 2017). The Cauca River Valley separates the Central Cordillera from the Western Cordillera which includes Late Cretaceous oceanic rocks accreted to the South American plate during Early Cretaceous (Kerr et al., 1997; Villagómez and Spikings, 2013), then intruded by Miocene plutons and covered volcanic rocks from intermediate to tholeiitic character (Bissig et al., 2017; Restrepo and Toussaint, 1990).

\subsection{Late Cretaceous to Paleogene magmatism of the Colombian Andes}

Late Cretaceous arc-related granitoids (i.e., Antioquia batholith) intrudes the Great Caribbean Arc (Fig. 1). These have been identified all along the Central Cordillera of Colombia (Ibáñez et al., 2007; Villagómez et al., 2011; Restrepo-Moreno, et al., 2009; Leal-Mejía, 2011) as well as in the Real 


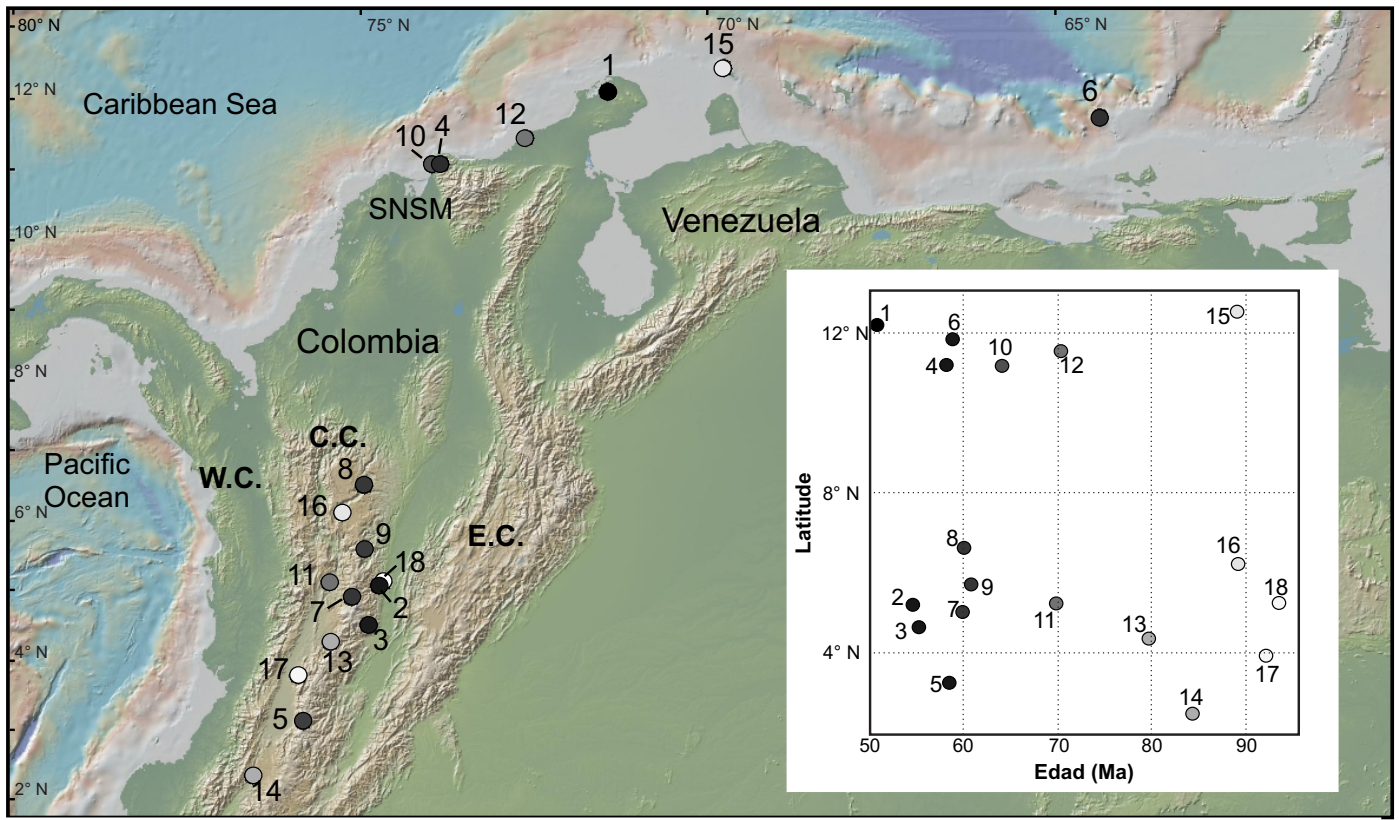

FIG. 1. Geographic distribution of the Late Cretaceous to Paleogene magmatism in the northwestern part of the South American Plate. 1. Parashi Pluton; 2. El Hatillo Stock; 3. El Bosque Batholith; 4. Santa Marta Batholith; 5. Santa Bárbara Batholith; 6. La Blanquilla Pluton; 7. Manizales Stock; 8. Antioquia Batholith; 9. Sonson Batholith; 10. Playa Salguero Stock; 11. Irra Stock; 12. Baja Guajira Granitoid; 13. Córdoba Stock; 14. Jejenes Stock; 15. Aruba Batholith; 16. Media Luna Stock; 17. Buga Batholith; 18. Mariquita Stock. Abbreviation: W.C.: Western Cordillera; C.C.: Central Cordillera; E.C.: Eastern Cordillera.

Cordillera in Ecuador (Vallejo et al., 2009). These are the main vestiges of a well established subduction zone on the western margin of South America that lasted until at least the middle Eocene (Fig.1), when magmatism stopped due to difficulties of the Caribbean plateau to subduct and the northward migration of the Caribbean and South America plates (Aspden et al., 1987; Pindell et al., 2005; Spikings et al., 2005; Vallejo et al., 2009; Cardona et al., 2010; Villagómez et al., 2011; Bayona et al., 2012).

\subsubsection{Antioquia batholith and related stocks}

The Antioquia batholith is the only Late-Cretaceous intrusive body recognized in the Central Cordillera of Colombia and constitutes the first record of the continental arc magmatism in NW South America after ca. 20 m.y. of magmatic quiescence (Bustamante et al., 2016).

Along decades, different geochronometers as $\mathrm{U}-\mathrm{Pb},{ }^{40} \mathrm{Ar} /{ }^{39} \mathrm{Ar}, \mathrm{K}-\mathrm{Ar}, \mathrm{U}-\mathrm{Th} / \mathrm{He}$, Fission tracks, $\mathrm{Re} / \mathrm{Os}$ and $\mathrm{Rb} / \mathrm{Sr}$ have been used on the Antioquia Batholith, obtaining a considerable dataset. A review of all available geochronological ages are listed in table 1, where basic data are gathered including sampling site, method, material, error, among others.

In order to establish the formation age of the batholith, extensive U-Pb geochronological studies in zircon, using different techniques (LA-ICP-MS, TIMS and SHRIMP) have been performed (Fig. 2; Table 1). U-Pb have yielded crystallization ages between 97 and $58 \mathrm{Ma}$ (Fig. 3; Ordóñez-Carmona et al., 2006; Correa et al., 2006; Restrepo-Moreno et al., 2007; Ibáñez-Mejía et al., 2007; Leal-Mejía, 2011; Villagómez et al., 2011). The whole intrusive complex has a scanty compositional variation, ranging from granodiorite to tonalite with minor gabbroic facies (Feininger and Botero, 1982). Five spatially related satellite stocks have also been related to this major Cretaceous magmatic body. These satellite stocks are known as the Altavista, La Culebra, Ovejas, La Unión and San Diego. Their compositions range from granite to granodiorite, except the San Diego stock which has a gabbroic composition (Fig. 3A). Based on extensive zircon U-Pb data, Leal-Mejía (2011) defined four main pulses which constructed the Antioquia batholith (i) An older pulse between 
TABLE 1. REVIEW OF GEOCHRONOLOGICAL DATA FROM THE ANTIOQUIA BATHOLITH AND SATELLITE BODIES. SAMPLE LOCATIONS ARE PLOTTED IN FIGURE 2.

\begin{tabular}{|c|c|c|c|c|c|c|c|c|c|c|}
\hline FID & $\begin{array}{c}\text { Sample } \\
\text { code }\end{array}$ & Latitude* & Longitude* & $\begin{array}{l}\text { Geological } \\
\text { Unit }\end{array}$ & Rock type & $\begin{array}{l}\text { Age } \\
\text { (Ma) }\end{array}$ & $\begin{array}{l}\text { Error } \\
( \pm \text { Ma) }\end{array}$ & Method & Material & Reference \\
\hline 66 & R6834 & 6.499 & 74.753 & $\mathrm{CS}$ & Quartzdiorite & 60.1 & 1.2 & U-Pb (LA) & Zircon & 5 \\
\hline 42 & 1 & 6.418 & 75.426 & $\mathrm{AB}$ & Granodiorite & 60 & - & $\mathrm{Rb}-\mathrm{Sr}$ & Biotite & 3 \\
\hline 35 & 2 & 6.497 & 75.388 & $\mathrm{AB}$ & Granodiorite & 58 & - & $\mathrm{Rb}-\mathrm{Sr}$ & Biotite & 3 \\
\hline 19 & 4 & 6.948 & 75.422 & $\mathrm{AB}$ & Granodiorite & 68 & - & $\mathrm{Rb}-\mathrm{Sr}$ & Biotite & 3 \\
\hline 10 & 12038453 & 5.953 & 75.355 & US & Quartzdiorite & 73.5 & 1.3 & U-Pb (LA) & Zircon & 17 \\
\hline 10 & 12038453 & 5.953 & 75.355 & US & Quartzdiorite & 82.8 & 1.5 & U-Pb (LA) & Zircon & 17 \\
\hline 34 & $1302 \mathrm{~A}$ & 6.497 & 75.413 & $\mathrm{AB}$ & Quartzdiorite & 79 & 3 & $\mathrm{~K}-\mathrm{Ar}$ & Biotite & 1 \\
\hline 14 & $\mathrm{AC} 75$ & 6.227 & 75.638 & AS & Diorite & 96 & 0.39 & U-Pb (LA) & Zircon & 16 \\
\hline 69 & BA12 & 6.037 & 74.999 & $\mathrm{AB}$ & Granodiorite & 98 & 27 & $\mathrm{Rb}-\mathrm{Sr}$ & Whole Rock & 6 \\
\hline 24 & BA2 & 6.733 & 75.620 & $\mathrm{AB}$ & Granodiorite & 98 & 27 & $\mathrm{Rb}-\mathrm{Sr}$ & Whole Rock & 6 \\
\hline 49 & BA32 & 6.733 & 75.620 & $\mathrm{AB}$ & Granodiorite & 98 & 27 & $\mathrm{Rb}-\mathrm{Sr}$ & Whole Rock & 6 \\
\hline 48 & BA4 & 6.216 & 75.200 & $\mathrm{AB}$ & Granodiorite & 83 & 4 & $\mathrm{Rb}-\mathrm{Sr}$ & Whole Rock & 7 \\
\hline 53 & BA6 & 6.512 & 75.174 & $\mathrm{AB}$ & Granodiorite & 98 & 27 & $\mathrm{Rb}-\mathrm{Sr}$ & Whole Rock & 6 \\
\hline 20 & BA7 & 6.943 & 75.438 & $\mathrm{AB}$ & Granodiorite & 98 & 27 & $\mathrm{Rb}-\mathrm{Sr}$ & Whole Rock & 6 \\
\hline 65 & BA9 & 6.522 & 74.782 & $\mathrm{AB}$ & Granodiorite & 98 & 27 & $\mathrm{Rb}-\mathrm{Sr}$ & Whole Rock & 6 \\
\hline 28 & $\mathrm{BC} 1$ & 6.799 & 75.215 & $\mathrm{AB}$ & Granodiorite & 55.8 & 2.7 & FT & Zircon & 11 \\
\hline 30 & $\mathrm{BC} 2$ & 6.664 & 75.222 & $\mathrm{AB}$ & Granodiorite & 63.3 & 3.2 & FT & Zircon & 11 \\
\hline 41 & $\mathrm{BC} 3$ & 6.408 & 75.397 & $\mathrm{AB}$ & Granodiorite & 49.4 & 2 & FT & Zircon & 11 \\
\hline 18 & $\mathrm{BC} 4$ & 6.964 & 75.434 & $\mathrm{AB}$ & Granodiorite & 62.8 & 2.9 & FT & Zircon & 11 \\
\hline 33 & $\mathrm{BC} 5$ & 6.512 & 75.410 & $\mathrm{AB}$ & Monzogranite & 60.4 & 2.3 & FT & Zircon & 11 \\
\hline 31 & BC6 & 6.616 & 75.154 & $\mathrm{AB}$ & Granodiorite & 58 & 2.3 & FT & Zircon & 11 \\
\hline 56 & $\mathrm{BC} 7$ & 6.536 & 75.077 & $\mathrm{AB}$ & Granodiorite & 49.1 & 2.5 & FT & Zircon & 11 \\
\hline 43 & $\mathrm{BC} 8$ & 6.204 & 75.320 & $\mathrm{AB}$ & Quartzdiorite & 53.4 & 2.7 & FT & Zircon & 11 \\
\hline 68 & BC9 & 6.042 & 74.999 & $\mathrm{AB}$ & Quartzdiorite & 67.1 & 2.7 & FT & Zircon & 11 \\
\hline 61 & CRI1 & 6.484 & 74.923 & $\mathrm{AB}$ & Dike & 61.8 & 1.3 & U-Pb (LA) & Zircon & 5 \\
\hline 61 & CRI1 & 6.484 & 74.923 & $\mathrm{AB}$ & Dike & 74.4 & 1.2 & U-Pb (LA) & Zircon & 5 \\
\hline 76 & DV148 & 6.421 & 75.385 & $\mathrm{AB}$ & Granodiorite & 55.4 & 5.2 & FT & Zircon & 13 \\
\hline 55 & DV153 & 6.540 & 75.122 & $\mathrm{AB}$ & Granodiorite & 69.7 & 8.6 & FT & Apatite & 13 \\
\hline 77 & DV53 & 6.311 & 75.505 & $\mathrm{AB}$ & Diorite & 13.4 & 1.4 & $\mathrm{U}-\mathrm{Th} / \mathrm{He}$ & Apatite & 14 \\
\hline 77 & DV53 & 6.311 & 75.505 & $\mathrm{AB}$ & Diorite & 72.9 & 18.8 & FT & Apatite & 14 \\
\hline 78 & DV54 & 6.328 & 75.481 & $\mathrm{AB}$ & Diorite & 64.1 & 5.4 & $\mathrm{Ar} / \mathrm{Ar}$ & Hornblende & 14 \\
\hline 78 & DV54 & 6.328 & 75.481 & $\mathrm{AB}$ & Diorite & 70.4 & 6.3 & $\mathrm{Ar} / \mathrm{Ar}$ & Hornblende & 14 \\
\hline 78 & DV54 & 6.328 & 75.481 & $\mathrm{AB}$ & Diorite & 74.4 & 10.6 & FT & Apatite & 14 \\
\hline 78 & DV54 & 6.328 & 75.481 & $\mathrm{AB}$ & Diorite & 71 & 1.9 & $\mathrm{Ar} / \mathrm{Ar}$ & Hornblende & 14 \\
\hline 44 & DV56 & 6.056 & 75.212 & $\mathrm{AB}$ & Granite & 87.2 & 1.6 & U-Pb (LA) & Zircon & 15 \\
\hline 75 & DV58 & 6.018 & 75.135 & $\mathrm{AB}$ & Granite & 32 & 1.9 & $\mathrm{U}-\mathrm{Th} / \mathrm{He}$ & Apatite & 14 \\
\hline 75 & DV58 & 6.018 & 75.135 & $\mathrm{AB}$ & Granite & 45.5 & 3.1 & $\mathrm{C}$ & Zircon & 14 \\
\hline 75 & DV58 & 6.018 & 75.135 & $\mathrm{AB}$ & Granite & 56.5 & 8.6 & $\mathrm{Ar} / \mathrm{Ar}$ & K Felspar & 14 \\
\hline 75 & DV58 & 6.018 & 75.135 & $\mathrm{AB}$ & Granite & 58.5 & 8 & FT & Apatite & 14 \\
\hline
\end{tabular}


table 1 continued.

\begin{tabular}{|c|c|c|c|c|c|c|c|c|c|c|}
\hline FID & $\begin{array}{c}\text { Sample } \\
\text { code }\end{array}$ & Latitude* & Longitude* & $\begin{array}{c}\text { Geological } \\
\text { Unit }\end{array}$ & Rock type & $\begin{array}{l}\text { Age } \\
\text { (Ma) }\end{array}$ & $\begin{array}{l}\text { Error } \\
( \pm \text { Ma) }\end{array}$ & Method & Material & Reference \\
\hline 75 & DV58 & 6.018 & 75.135 & $\mathrm{AB}$ & Granite & 62.6 & 1.1 & $\mathrm{Ar} / \mathrm{Ar}$ & K Felspar & 14 \\
\hline 75 & DV58 & 6.018 & 75.135 & $\mathrm{AB}$ & Granite & 72.3 & 0.3 & $\mathrm{Ar} / \mathrm{Ar}$ & Biotite & 14 \\
\hline 75 & DV58 & 6.018 & 75.135 & $\mathrm{AB}$ & Granite & 73.2 & 0.8 & $\mathrm{Ar} / \mathrm{Ar}$ & Biotite & 14 \\
\hline 75 & DV58 & 6.018 & 75.135 & $\mathrm{AB}$ & Granite & 31 & 1.4 & $\mathrm{U}-\mathrm{Th} / \mathrm{He}$ & Apatite & 14 \\
\hline 75 & DV58 & 6.018 & 75.135 & $\mathrm{AB}$ & Granite & 45.2 & 1.2 & $\mathrm{U}-\mathrm{Th} / \mathrm{He}$ & Zircon & 14 \\
\hline 75 & DV58 & 6.018 & 75.135 & $\mathrm{AB}$ & Granite & 63.4 & 0.5 & $\mathrm{Ar} / \mathrm{Ar}$ & K Felspar & 14 \\
\hline 75 & DV58 & 6.018 & 75.135 & $\mathrm{AB}$ & Granite & 71.4 & 0.2 & $\mathrm{Ar} / \mathrm{Ar}$ & Biotite & 14 \\
\hline 75 & DV58 & 6.018 & 75.135 & $\mathrm{AB}$ & Granite & 93.5 & 1.5 & $\mathrm{U}-\mathrm{Pb}$ (LA) & Zircon & 14 \\
\hline 70 & DV63 & 5.968 & 74.959 & $\mathrm{AB}$ & Granite & 74.8 & 7.4 & FT & Zircon & 13 \\
\hline 72 & DV64 & 5.982 & 74.955 & $\mathrm{AB}$ & Granodiorite & 63.2 & 0.3 & $\mathrm{Ar} / \mathrm{Ar}$ & Plagioclase & 14 \\
\hline 17 & DV70 & 6.971 & 75.426 & $\mathrm{AB}$ & Granodiorite & 69.1 & 0.2 & $\mathrm{Ar} / \mathrm{Ar}$ & Biotite & 14 \\
\hline 54 & El1 & 6.529 & 75.123 & LV & Mineralization & 60 & 0.3 & Re-Os & molybdenite & 5 \\
\hline 52 & ER 1 & 6.499 & 75.099 & ERP & Porphyry & 59.9 & 0.9 & $\mathrm{U}-\mathrm{Pb}(\mathrm{LA})$ & Zircon & 5 \\
\hline 62 & G1 & 6.508 & 74.911 & - & Alteration & 58.7 & 0.3 & Re-Os & Sericite & 5 \\
\hline 60 & G29 & 6.508 & 74.917 & - & Tonalite & 60.7 & 1 & $\mathrm{U}-\mathrm{Pb}(\mathrm{LA})$ & Zircon & 5 \\
\hline 79 & G9 & 6.509 & 74.910 & - & Mineralization & 58 & 2 & $\mathrm{~K}-\mathrm{Ar}$ & molybdenite & 5 \\
\hline 59 & GRII1 & 6.511 & 74.912 & $\mathrm{AB}$ & Tonalite & 59.2 & 1.2 & $\mathrm{U}-\mathrm{Pb}(\mathrm{LA})$ & Zircon & 5 \\
\hline 11 & $\mathrm{JJ} 253$ & 5.943 & 75.312 & US & Quartzdiorite & 64 & 4 & $\mathrm{~K}-\mathrm{Ar}$ & Biotite & 10 \\
\hline 58 & LF10 & 6.637 & 74.846 & $\mathrm{AB}$ & Granodiorite & 79.5 & 1.3 & SHRIMP & Zircon & 5 \\
\hline 32 & M11 & 6.533 & 75.392 & $\mathrm{AB}$ & Granitoid & 83.75 & 0.36 & TIMS & Zircon & 4 \\
\hline 64 & no name & 6.549 & 74.751 & $\mathrm{AB}$ & Granodiorite & 68 & 2 & $\mathrm{~K}-\mathrm{Ar}$ & - & 2 \\
\hline 23 & Osos 15 & 6.764 & 75.488 & - & Soil & 2.79 & 0.13 & FT & Zircon & 12 \\
\hline 74 & PGA05 & 5.978 & 74.953 & $\mathrm{AB}$ & Granitoid & 88.46 & 0.63 & TIMS & Zircon & 4 \\
\hline 51 & $\begin{array}{c}\text { Santo } \\
\text { Domingo 1 }\end{array}$ & 6.449 & 75.134 & - & - & 59.1 & 0.3 & Re-Os & molybdenite & 5 \\
\hline 8 & SML1 & 6.236 & 75.517 & MLS & Granodiorite & 89.1 & 1.3 & $\mathrm{U}-\mathrm{Pb}(\mathrm{LA})$ & Zircon & 18 \\
\hline 5 & SPK0526 & 6.356 & 75.588 & $\mathrm{AB}$ & Quartzdiorite & 70 & 3 & $\mathrm{~K}-\mathrm{Ar}$ & Biotite & 8 \\
\hline 27 & SPK0528 & 6.768 & 75.279 & $\mathrm{AB}$ & Granodiorite & 74 & 3 & $\mathrm{~K}-\mathrm{Ar}$ & Biotite & 8 \\
\hline 50 & SPK0529 & 6.270 & 75.094 & $\mathrm{AB}$ & Quartzdiorite & 71 & 3 & $\mathrm{~K}-\mathrm{Ar}$ & Biotite & 8 \\
\hline 25 & SPK0530 & 6.692 & 75.575 & $\mathrm{AB}$ & Quartzdiorite & 72 & 3 & $\mathrm{~K}-\mathrm{Ar}$ & Biotite & 8 \\
\hline 67 & SPK0532 & 6.042 & 75.008 & $\mathrm{AB}$ & Quartzdiorite & 80 & 3 & $\mathrm{~K}-\mathrm{Ar}$ & Biotite & 8 \\
\hline 37 & SR11 & 6.460 & 75.370 & $\mathrm{AB}$ & Quartzdiorite & 43.4 & 2.2 & $\mathrm{U}-\mathrm{Th} / \mathrm{He}$ & Apatite & 9 \\
\hline 38 & SR15 & 6.450 & 75.370 & $\mathrm{AB}$ & Quartzdiorite & 48.9 & 2.4 & $\mathrm{U}-\mathrm{Th} / \mathrm{He}$ & Apatite & 9 \\
\hline 39 & SR19 & 6.450 & 75.360 & $\mathrm{AB}$ & Quartzdiorite & 40.7 & 2 & $\mathrm{U}-\mathrm{Th} / \mathrm{He}$ & Apatite & 9 \\
\hline 36 & SR2 & 6.470 & 75.380 & $\mathrm{AB}$ & Quartzdiorite & 36.6 & 1.8 & $\mathrm{U}-\mathrm{Th} / \mathrm{He}$ & Apatite & 9 \\
\hline 2 & SR26 & 6.380 & 75.590 & $\mathrm{AB}$ & Quartzdiorite & 46.7 & 2.3 & $\mathrm{U}-\mathrm{Th} / \mathrm{He}$ & Apatite & 9 \\
\hline 3 & SR31 & 6.370 & 75.590 & $\mathrm{AB}$ & Quartzdiorite & 42.9 & 2.1 & $\mathrm{U}-\mathrm{Th} / \mathrm{He}$ & Apatite & 9 \\
\hline 1 & SR32 & 6.380 & 75.600 & $\mathrm{AB}$ & Quartzdiorite & 41.3 & 2.1 & $\mathrm{U}-\mathrm{Th} / \mathrm{He}$ & Apatite & 9 \\
\hline 82 & SR41 & 6.410 & 75.410 & $\mathrm{AB}$ & Quartzdiorite & 25.1 & 1.3 & $\mathrm{U}-\mathrm{Th} / \mathrm{He}$ & Apatite & 9 \\
\hline
\end{tabular}


table 1 continued.

\begin{tabular}{|c|c|c|c|c|c|c|c|c|c|c|}
\hline FID & $\begin{array}{c}\text { Sample } \\
\text { code }\end{array}$ & Latitude* & Longitude* & $\begin{array}{c}\text { Geological } \\
\text { Unit }\end{array}$ & Rock type & $\begin{array}{l}\text { Age } \\
\text { (Ma) }\end{array}$ & $\begin{array}{c}\text { Error } \\
( \pm \text { Ma) }\end{array}$ & Method & Material & Reference \\
\hline 7 & SR44 & 6.340 & 75.580 & $\mathrm{AB}$ & Quartzdiorite & 26.6 & 1.3 & $\mathrm{U}-\mathrm{Th} / \mathrm{He}$ & Apatite & 9 \\
\hline 4 & SR45 & 6.360 & 75.590 & $\mathrm{AB}$ & Quartzdiorite & 45.7 & 2.3 & $\mathrm{U}-\mathrm{Th} / \mathrm{He}$ & Apatite & 9 \\
\hline 12 & SR46 & 6.360 & 75.590 & $\mathrm{AB}$ & Quartzdiorite & 40.8 & 2 & $\mathrm{U}-\mathrm{Th} / \mathrm{He}$ & Apatite & 9 \\
\hline 6 & SR48 & 6.350 & 75.580 & $\mathrm{AB}$ & Quartzdiorite & 32.2 & 1.6 & $\mathrm{U}-\mathrm{Th} / \mathrm{He}$ & Apatite & 9 \\
\hline 40 & SR6 & 6.430 & 75.370 & $\mathrm{AB}$ & Quartzdiorite & 33.7 & 1.7 & $\mathrm{U}-\mathrm{Th} / \mathrm{He}$ & Apatite & 9 \\
\hline 13 & SR9 & 6.460 & 75.370 & $\mathrm{AB}$ & Quartzdiorite & 43.6 & 2.2 & $\mathrm{U}-\mathrm{Th} / \mathrm{He}$ & Apatite & 9 \\
\hline 26 & SRCC1 & 6.860 & 75.180 & $\mathrm{AB}$ & Quartzdiorite & 22.8 & 1.1 & $\mathrm{U}-\mathrm{Th} / \mathrm{He}$ & Apatite & 9 \\
\hline 81 & SRCC2 & 6.800 & 75.140 & $\mathrm{AB}$ & Quartzdiorite & 23.9 & 1.2 & $\mathrm{U}-\mathrm{Th} / \mathrm{He}$ & Apatite & 9 \\
\hline 29 & SRCC3 & 6.760 & 75.120 & $\mathrm{AB}$ & Quartzdiorite & 24.2 & 1.2 & $\mathrm{U}-\mathrm{Th} / \mathrm{He}$ & Apatite & 9 \\
\hline 57 & WR200 & 6.038 & 74.746 & LCS & Tonalite & 87.5 & 1.3 & U-Pb (LA) & Zircon & 5 \\
\hline 21 & WR201 & 6.852 & 75.329 & $\mathrm{AB}$ & Tonalite & 75.1 & 1.3 & $\mathrm{U}-\mathrm{Pb}$ (LA) & Zircon & 5 \\
\hline 80 & WR202 & 6.789 & 75.202 & $\mathrm{AB}$ & Diorite & 84.2 & 2.3 & U-Pb (LA) & Zircon & 5 \\
\hline 63 & WR221 & 6.509 & 74.878 & $\mathrm{AB}$ & Quartzdiorite & 87.4 & 1.3 & U-Pb (LA) & Zircon & 5 \\
\hline 22 & WR305 & 6.825 & 75.460 & $\mathrm{AB}$ & Tonalite & 73.9 & 1.3 & U-Pb (LA) & Zircon & 5 \\
\hline 76 & DV148 & 6.421 & 75.385 & $\mathrm{AB}$ & Granodiorite & 53 & 4.8 & FT & Apatite & 13 \\
\hline 55 & DV153 & 6.540 & 75.122 & $\mathrm{AB}$ & Granodiorite & 66.6 & 8 & FT & Zircon & 13 \\
\hline 44 & DV56 & 6.056 & 75.212 & $\mathrm{AB}$ & Granite & 40.1 & 1 & $\mathrm{U}-\mathrm{Th} / \mathrm{He}$ & Zircon & 14 \\
\hline 44 & DV56 & 6.056 & 75.212 & $\mathrm{AB}$ & Granite & 40.2 & 2.6 & $\mathrm{U}-\mathrm{Th} / \mathrm{He}$ & Zircon & 13 \\
\hline 44 & DV56 & 6.056 & 75.212 & $\mathrm{AB}$ & Granite & 65.5 & 6 & FT & Zircon & 13 \\
\hline 70 & DV63 & 5.978 & 74.959 & $\mathrm{AB}$ & Aplite & 20.6 & 1.4 & $\mathrm{U}-\mathrm{Th} / \mathrm{He}$ & Apatite & 13 \\
\hline 70 & DV63 & 5.978 & 74.959 & $\mathrm{AB}$ & Aplite & 20.9 & 1.2 & $\mathrm{U}-\mathrm{Th} / \mathrm{He}$ & Apatite & 14 \\
\hline 70 & DV63 & 5.978 & 74.959 & $\mathrm{AB}$ & Aplite & 64.1 & 9.6 & FT & Apatite & 13 \\
\hline 72 & DV64 & 5.982 & 74.955 & $\mathrm{AB}$ & Granodiorite & 58.9 & 9.6 & $\mathrm{Ar} / \mathrm{Ar}$ & Plagioclase & 13 \\
\hline 72 & DV64 & 5.982 & 74.955 & $\mathrm{AB}$ & Granodiorite & 59.8 & 10.2 & FT & Apatite & 13 \\
\hline 72 & DV64 & 5.982 & 74.955 & $\mathrm{AB}$ & Granodiorite & 62.6 & 0.7 & $\mathrm{Ar} / \mathrm{Ar}$ & Plagioclase & 13 \\
\hline 17 & DV70 & 6.971 & 75.426 & $\mathrm{AB}$ & Granodiorite & 39.1 & 2.1 & $\mathrm{U}-\mathrm{Th} / \mathrm{He}$ & Apatite & 13 \\
\hline 17 & DV70 & 6.971 & 75.426 & $\mathrm{AB}$ & Granodiorite & 54.8 & 5.8 & FT & Apatite & 13 \\
\hline 17 & DV70 & 6.971 & 75.426 & $\mathrm{AB}$ & Granodiorite & 58.1 & 5.2 & FT & Zircon & 13 \\
\hline 17 & DV70 & 6.971 & 75.426 & $\mathrm{AB}$ & Granodiorite & 68.6 & 1.5 & $\mathrm{Ar} / \mathrm{Ar}$ & Biotite & 13 \\
\hline 17 & DV70 & 6.971 & 75.426 & $\mathrm{AB}$ & Granodiorite & 68.9 & 0.6 & $\mathrm{Ar} / \mathrm{Ar}$ & Biotite & 13 \\
\hline 83 & JPZ-178 & 6.744 & 75.7900 & SQ & Quartzdiorite & 71.6 & 1.2 & U-Pb (LA) & Zircon & 19 \\
\hline 84 & MGO-238 & 6.772 & 75.774 & SQ & Quartzdiorite & 71.9 & 1.9 & U-Pb (LA) & Zircon & 19 \\
\hline
\end{tabular}

Abbreviation: FID: Figure Identification number, *Decimal degrees; AB: Antioqueño Batholith; US: La Unión Stock; OB: Ovejas Batholith; AS: Altavista Stock; MLS: Media Luna Stock; LCS: La Culebra Stock; Q: Aluvial deposit; V: Volcanic deposit; ERP: El Rayo porphyry intrusive; CS: Caracolí Stock; LV: El Limón vein; SQ: Sabanalarga Quartzdiorite; FT: Fission Tracks; U-PB (LA): U-Pb LA-MC-ICP-MS; TIMS: U-Pb ID-TIMS; SHRIMP: U-Pb SHRIMP.

References: 1. Botero and González, 1983; 2. Feininger and Botero, 1982; 3. Fujiyoshi et al., 1976; 4. Ibáñez Mejía, 2011; 5. Leal Mejía, 2011; 6. Ordóñez Carmona and Pimentel, 2001; 7. Ordóñez Carmona, 1997; 8. Pérez, 1967; 9. Restrepo Moreno et al., 2009; 10. Restrepo, 1991; 11. Sáenz et al., 1996; 12. Toro et al., 2006; 13. Villagómez and Spikings, 2013; 14. Villagómez, $2010 ; 15$. Villagómez et al., 2011; 16. Correa et al., 2006; 17. Cochrane, et al., 2014; 18. Restrepo, et al., 2012; 19. Zapata et al., 2017. 


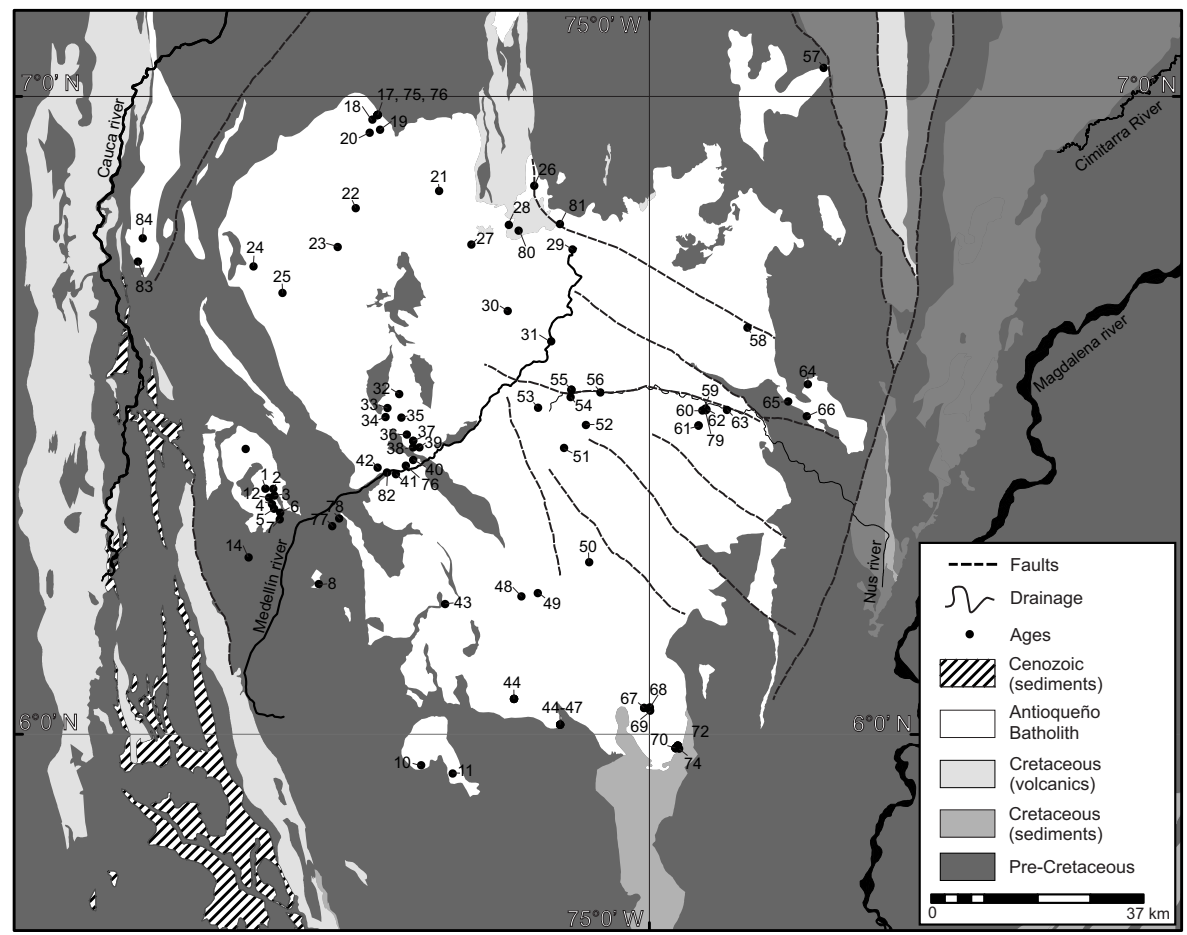

FIG. 2. Summary of geochronological ages (Ma) obtained for the Antioquia Batholith and satellite bodies using different methods. Data from table 1.

95 and 87 Ma located to the south of the batholith, including the San Diego and Altavista stocks; (ii) a second pulse between 89 and $82 \mathrm{Ma}$, mainly located on the margins of the pluton, including La Culebra and a more felsic facies of the Altavista stocks; (iii) a third pulse between 81 and $72 \mathrm{Ma}$ that includes the Ovejas stock; (iv) the fourth and youngest pulse of Eocene age ( $\sim 63$ to $58 \mathrm{Ma})$ is identified in the central-eastern portion of the batholith (Fig. 3B). This last magmatic pulse is also correlatable with other plutons located south on the Central Cordillera such as Hatillo, Manizales, El Bosque, Norcasia and Sonsón (Bayona et al., 2012; Bustamante et al., 2017) and the Santa Marta batholith and the Parashi stock located at the Colombian caribbean (Cardona et al., 2011; Cardona et al., 2014; Salazar et al., 2016).

\section{Methods}

\subsection{U-Pb geochronology}

This paper presents five new U-Pb (LA-ICPMS) ages in zircon (crystallization ages) from $\mathrm{La}$
Unión Stock and Ovejas Batholith. These ages were obtained at the Laboratorio de Estudios Isotópicos (LEI), Centro de Geociencias (CGEO), Universidad Nacional Autónoma de México (UNAM) following procedures described in Solari et al. (2010). Zircon crystals were separated using conventional techniques of rock crushing, sieving, Frantz isodynamic magnetic separator, panning, and heavy liquid separation. Crystal ablation was performed using an ArF excimer laser (Resolution M-50) operated at $193 \mathrm{~nm}, 5 \mathrm{~Hz}$ and $\sim 6 \mathrm{~J} / \mathrm{cm}$. The Plešovice reference zircon ( $c a .337 \mathrm{Ma}$; Sláma et al., 2008) was used in combination with NIST 610 standard glass to correct for instrumental drift and down-hole fractionation and to recalculate elemental concentrations, using the UPb.age script for R (Solari and Tanner, 2011) and Iolite (Paton et al., 2010). Because its signal is swamped by the ${ }^{204} \mathrm{Hg}$ contained in the carrier gases, ${ }^{204} \mathrm{~Pb}$ was not analyzed during this study. Common $\mathrm{Pb}$ correction, where needed, was thus performed employing the algebraic method of Andersen (2002). Concordia and age distribution plots, as well as age error calculations, were performed using Isoplot v. 3.70 (Ludwig, 2004). 

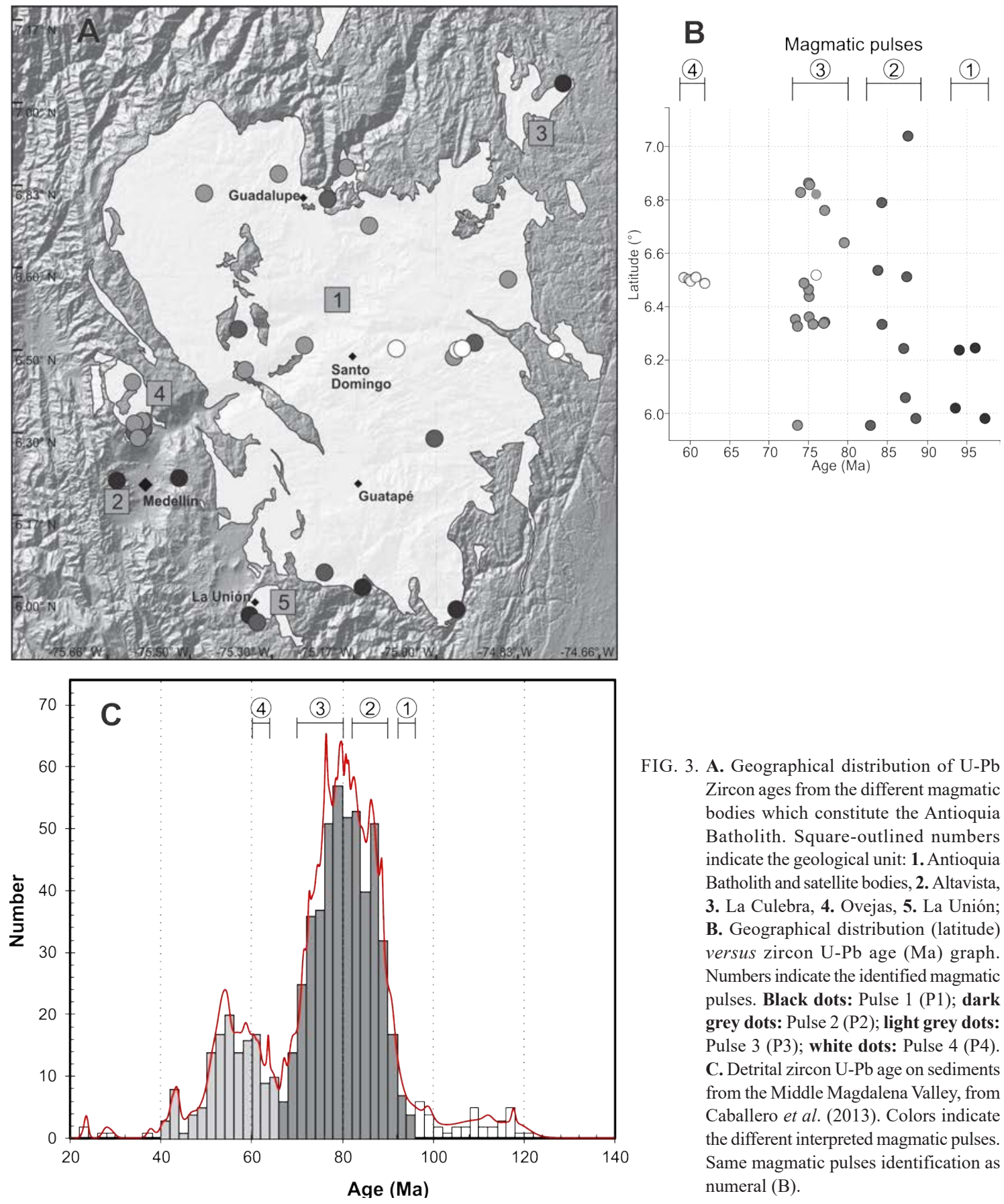

FIG. 3. A. Geographical distribution of $\mathrm{U}-\mathrm{Pb}$ Zircon ages from the different magmatic bodies which constitute the Antioquia Batholith. Square-outlined numbers indicate the geological unit: 1. Antioquia Batholith and satellite bodies, 2. Altavista, 3. La Culebra, 4. Ovejas, 5. La Unión; B. Geographical distribution (latitude) versus zircon $\mathrm{U}-\mathrm{Pb}$ age $(\mathrm{Ma})$ graph. Numbers indicate the identified magmatic pulses. Black dots: Pulse 1 (P1); dark grey dots: Pulse $2(\mathrm{P} 2)$; light grey dots: Pulse 3 (P3); white dots: Pulse 4 (P4). C. Detrital zircon $\mathrm{U}-\mathrm{Pb}$ age on sediments from the Middle Magdalena Valley, from Caballero et al. (2013). Colors indicate the different interpreted magmatic pulses. Same magmatic pulses identification as numeral (B).

\subsection{Whole-rock geochemistry}

Whole rock geochemistry was performed on the same samples where U-Pb ages were obtained, except for the A.G.1.6 sample (La Unión Stock), which was completely weathered. Major elements analysis were performed by X-ray fluorescence with a Siemens SRS-300 equipment, following the procedures described by Lozano-Santa Cruz et al. (1995). Trace elements analysis were performed 
on the LEI by ICP-MS using a Thermo Series XII equipment, under procedures described by Mori et al. (2009). Two additional digestion steps were added in order to achieve complete dissolution of highly refractory minerals (e.g., zircon) as described in Duque-Trujillo et al. (2014).

Due to the impossibility of accessing raw data from Leal-Mejía (2011) a graphic comparison was made between the data of this author and the data here presented.

\section{Results}

\subsection{Petrography and geochemistry}

Petrographic analyses were performed on four samples from the Ovejas Batholith and one sample from a magmatic mafic enclave. The sample belonging to La Unión Stock could not be analyzed due to its high degree of weathering.

The analyzed samples were classified as granodiorites. Broadly speaking, the samples are hypidiomorphic, equigranular, coarse to medium grained. These are mainly composed of quartz, plagioclase, K-feldspar, hornblende, and biotite. Magmatic mafic enclaves are common, and those present the same mineralogical composition as the main magmatic mass with a high content of mafic minerals.

Plagioclase is usually classified as andesine although compositional zonation is frequent. K-feldspar is classified as orthoclase. The amphibole, classified as hornblende, usually presents a genetic relationship with biotite in clusters of crystals. The amphibole and biotite are frequently altered to chlorite and present local replacements to epidote-clinozoisite. These observations agree with the results obtained by Feininger and Botero (1982) and Álvarez (1983) for the Antioquia Batholith. Those authors, based on a large data-set, found that the petrographic characteristics of the main granitic mass of the Antioquia Batholith are very homogeneous, with a $\sim 97 \%$ of the samples classified as granodiorites to tonalities.

Four samples of the Ovejas Batholith were geochemically analyzed and their results are presented in table. 2. Three samples correspond to the main granodioritic mass of the Ovejas Batholith and one sample from a mafic enclave. Samples belonging to the granodioritic mass were classified as quartzdiorites and diorites, meanwhile the mafic enclave fall in the gabbro field (Fig. 4A). $\mathrm{SiO}_{2}$ vary from 61.9 to $66.7 \mathrm{wt} \%$, while $\mathrm{K}_{2} \mathrm{O}$ content is almost invariant around $\sim 1.8 \mathrm{wt} \%$ for the granitic samples, which fall in the calc-alkaline series of medium $\mathrm{K}$ (Fig. 4B). The mafic enclave has $52.3 \%$ of $\mathrm{Si}_{2} \mathrm{O}$ and higher $\mathrm{K}_{2} \mathrm{O}$, locating the sample on the Shoshonitic series. $\mathrm{MgO}$ values range from 1.5 to $2.3 \mathrm{wt} \%$ in the granitic samples, and have a value of $4.1 \mathrm{wt} \%$ for the mafic enclave. $\mathrm{Al}_{2} \mathrm{O}_{3}$ values range from 16.2 to $17.0 \mathrm{wt} \%$ within the granitic samples, and $17.9 \mathrm{wt} \%$ for the mafic enclave. From the four analyzed samples, two samples, (the mafic enclave and one granitic sample) fall in the metaluminous field, meanwhile the other two granitic rocks fall into the peraluminous field (Fig. 4C).

Primitive mantle-normalized multi-element diagrams for the Ovejas Batholith rocks are characterized by an enrichment of the Large Ion Lithophile Elements (LILE) over the High Field Strength Elements (HFSE) (Fig. 5A, C). These patterns are also characterized by negative $\mathrm{Nb}-\mathrm{Ta}$, $\mathrm{La}-\mathrm{Ce}$ and $\mathrm{Ti}$ anomalies, and positive $\mathrm{Pb}$, and $\mathrm{Zr}-\mathrm{Hf}$ anomalies (Fig. 5A, C). Although the mafic enclave has a similar pattern as the granitic rocks, it differs from those in some aspects, especially those related to less differentiated rocks (e.g., Zr-Hf anomaly, which is negative in the mafic enclave and positive in the granitic rocks).

Chondrite-normalized REE patterns show a well-defined LREE enrichment $\left([\mathrm{La} / \mathrm{Yb}]_{\mathrm{N}}\right.$ ratios vary from 6.4 to 8.6 in granitic rocks and 3.8 for the mafic enclave) and an almost flat HREE pattern $\left([\mathrm{Gd} / \mathrm{Yb}]_{\mathrm{N}}\right.$ ratios vary from 1.58 to 1.70 in granitic rocks and 1.51 for the mafic enclave) (Fig. 5B, D, $\mathrm{E}$ and $\mathrm{F})$. Unless all samples have similar patterns, $\mathrm{La} / \mathrm{Yb}$ ratios show that the mafic enclave rock is less depleted in REE than the granitic samples (Fig. 5B, D and E). Eu anomaly is present in three from the four analyzed samples (Fig. 5B). The mafic enclave shows a well-defined negative anomaly $\left(\mathrm{Eu} / \mathrm{Eu}^{*}=0.68\right)$, meanwhile the granitic rocks all samples have positive anomalies $\left(\mathrm{Eu} / \mathrm{Eu}^{*}\right.$ from 1.03 to 1.42 ) (Fig. 5G).

\subsection{U-Pb geochronology}

Zircon U-Pb crystallization ages (Table 3 ) were obtained by the LA-ICP-MS method in five samples (Fig. 6 and 7). One of them corresponds to the La Unión Stock, and four to the Ovejas Batholith. In 
TABLE 2. GEOCHEMISTRY DATA FROM THE ANALYZED SAMPLES.

\begin{tabular}{|c|c|c|c|c|}
\hline Sample & AG14B & AG12 & AG13 & AG14 \\
\hline Geological Unit & Ovejas Batholith & Ovejas Batholith & Ovejas Batholith & Ovejas Batholith \\
\hline Age (Ma) & & $75.48 \pm 0.95$ & $76.9 \pm 2.5$ & $74.3 \pm 1.9$ \\
\hline Latitude (N) & $6.325250^{\circ}$ & $6.331278^{\circ}$ & $6.331664^{\circ}$ & $6.325250^{\circ}$ \\
\hline Longitude (W) & $-75.597114^{\circ}$ & $-75.601819^{\circ}$ & $-75.598747^{\circ}$ & $-75.597114^{\circ}$ \\
\hline \multicolumn{5}{|c|}{ Major Elements in wt\% } \\
\hline $\mathrm{SiO}_{2}$ & 52.32 & 66.72 & 65.66 & 61.99 \\
\hline $\mathrm{TiO}_{2}$ & 1.15 & 0.48 & 0.486 & 0.677 \\
\hline $\mathrm{Al}_{2} \mathrm{O}_{3}$ & 17.89 & 16.21 & 16.96 & 17.02 \\
\hline $\mathrm{Fe}_{2} \mathrm{O}_{3}$ & 10.25 & 4.06 & 4.28 & 5.9 \\
\hline $\mathrm{MnO}$ & 0.24 & 0.094 & 0.111 & 0.126 \\
\hline $\mathrm{MgO}$ & 4.16 & 1.49 & 1.53 & 2.28 \\
\hline $\mathrm{CaO}$ & 6.19 & 3.72 & 3.97 & 5.22 \\
\hline $\mathrm{Na}_{2} \mathrm{O}$ & 3.58 & 4.1 & 4.18 & 3.71 \\
\hline $\mathrm{K}_{2} \mathrm{O}$ & 2.69 & 1.86 & 1.92 & 1.83 \\
\hline $\mathrm{P}_{2} \mathrm{O}_{5}$ & 0.22 & 0.122 & 0.117 & 0.166 \\
\hline LOI & 0.49 & 0.4 & 0.32 & 0.37 \\
\hline Total & 99.2 & 99.3 & 99.5 & 99.3 \\
\hline \multicolumn{5}{|c|}{ Trace Elements in ppm } \\
\hline $\mathrm{Li}$ & 41.21 & 27.76 & 22.21 & 23.65 \\
\hline $\mathrm{Be}$ & 1.36 & 1.39 & 1.02 & 1.18 \\
\hline $\mathrm{Mg}$ & 3.98 & 1.4 & 1.34 & 2.14 \\
\hline $\mathrm{P}$ & 0.275 & 0.147 & 0.129 & 0.197 \\
\hline $\mathrm{Ca}$ & 6.01 & 3.74 & 3.94 & 5.23 \\
\hline $\mathrm{Sc}$ & 21.2 & 3.62 & 5.16 & 9.55 \\
\hline $\mathrm{Ti}$ & 1.16 & 0.46 & 0.46 & 0.641 \\
\hline $\mathrm{V}$ & 150.75 & 40.12 & 39.14 & 83.76 \\
\hline $\mathrm{Cr}$ & 23.09 & 22.78 & 18.37 & 21.85 \\
\hline $\mathrm{Mn}$ & 0.246 & 0.084 & 0.1 & 0.120 \\
\hline $\mathrm{Fe}$ & 10.18 & 3.94 & 4.21 & 5.8 \\
\hline $\mathrm{Co}$ & 15.89 & 5.24 & 5.39 & 9.21 \\
\hline $\mathrm{Ni}$ & 6.01 & 5.06 & 4.01 & 4.18 \\
\hline $\mathrm{Cu}$ & 6.92 & 5.9 & 4.84 & 5.59 \\
\hline $\mathrm{Zn}$ & 141.17 & 78.41 & 81.48 & 80.93 \\
\hline $\mathrm{Ga}$ & 23.13 & 19.14 & 20 & 20.1 \\
\hline $\mathrm{Rb}$ & 87.48 & 43.1 & 48.14 & 49.48 \\
\hline $\mathrm{Sr}$ & 298.46 & 331.42 & 353.41 & 349.4 \\
\hline $\mathrm{Y}$ & 33.7 & 9.67 & 10.85 & 16.63 \\
\hline $\mathrm{Zr}$ & 124.99 & 164.36 & 135.94 & 108.44 \\
\hline
\end{tabular}


table 2 continued.

\begin{tabular}{|c|c|c|c|c|}
\hline Sample & AG14B & AG12 & AG13 & AG14 \\
\hline Geological Unit & Ovejas Batholith & Ovejas Batholith & Ovejas Batholith & Ovejas Batholith \\
\hline Age (Ma) & & $75.48 \pm 0.95$ & $76.9 \pm 2.5$ & $74.3 \pm 1.9$ \\
\hline Latitude (N) & $6.325250^{\circ}$ & $6.331278^{\circ}$ & $6.331664^{\circ}$ & $6.325250^{\circ}$ \\
\hline Longitude (W) & $-75.597114^{\circ}$ & $-75.601819^{\circ}$ & $-75.598747^{\circ}$ & $-75.597114^{\circ}$ \\
\hline $\mathrm{Nb}$ & 11.35 & 8.75 & 9.36 & 7.06 \\
\hline Mo & -0.08 & -0.16 & -0.08 & -0.15 \\
\hline $\mathrm{Sn}$ & 2.48 & 1.53 & 1.64 & 1.33 \\
\hline $\mathrm{Sb}$ & 0.08 & 0.07 & 0.09 & 0.09 \\
\hline Cs & 2.67 & 1.78 & 2.05 & 1.69 \\
\hline $\mathrm{Ba}$ & 810.1 & 739.26 & 675.62 & 665.98 \\
\hline $\mathrm{La}$ & 17.68 & 8.12 & 9.05 & 19.22 \\
\hline $\mathrm{Ce}$ & 40.52 & 15.16 & 16.22 & 32.5 \\
\hline $\operatorname{Pr}$ & 5.81 & 2.14 & 2.14 & 4.19 \\
\hline $\mathrm{Nd}$ & 24.72 & 8.5 & 8.41 & 15.05 \\
\hline $\mathrm{Sm}$ & 5.81 & 1.9 & 1.9 & 3.08 \\
\hline $\mathrm{Eu}$ & 1.32 & 0.884 & 0.869 & 1.05 \\
\hline $\mathrm{Tb}$ & 0.959 & 0.286 & 0.297 & 0.483 \\
\hline $\mathrm{Gd}$ & 5.98 & 1.87 & 1.9 & 3.07 \\
\hline Dy & 5.49 & 1.59 & 1.7 & 2.78 \\
\hline Ho & 1.11 & 0.312 & 0.343 & 0.553 \\
\hline Er & 3.32 & 0.888 & 0.974 & 1.63 \\
\hline $\mathrm{Yb}$ & 3.28 & 0.908 & 0.995 & 1.6 \\
\hline $\mathrm{Lu}$ & 0.505 & 0.150 & 0.165 & 0.256 \\
\hline $\mathrm{Hf}$ & 3.11 & 3.83 & 3.24 & 2.58 \\
\hline $\mathrm{Ta}$ & 0.823 & 0.724 & 0.716 & 0.652 \\
\hline W & 0.631 & 0.101 & 0.077 & 0.140 \\
\hline $\mathrm{Tl}$ & 0.784 & 0.508 & 0.500 & 0.492 \\
\hline $\mathrm{Pb}$ & 6.67 & 6.27 & 6.88 & 6.2 \\
\hline Th & 4.98 & 4.03 & 3.74 & 5.98 \\
\hline $\mathrm{U}$ & 0.925 & 1.13 & 1.38 & 1.18 \\
\hline
\end{tabular}

order to obtain the age of the last crystallization event, the preferred ablation target were crystal borders; nevertheless, some cores were analyzed in order to identify possible inherited ages.

\subsubsection{La Unión Stock}

One sample (AG 1.6) was analyzed for this pluton. Cathodoluminescence (CL) images show thin concentric overgrowths around ante-crystals (Fig. 6). Twenty-six analysis from this sample yield a weighted mean ${ }^{238} \mathrm{U} /{ }^{206} \mathrm{~Pb}$ age of $97.2 \pm 0.6 \mathrm{Ma}$ (Fig. 6). This age is dominated by the age of the magmatic overgrowths, leading to interpret this as the age of the latest magmatic activity during the La Unión Stock magmatism. Zircon cores yield ages only $\sim 4 \mathrm{Ma}$ older than the overgrowths (102-100 Ma). 

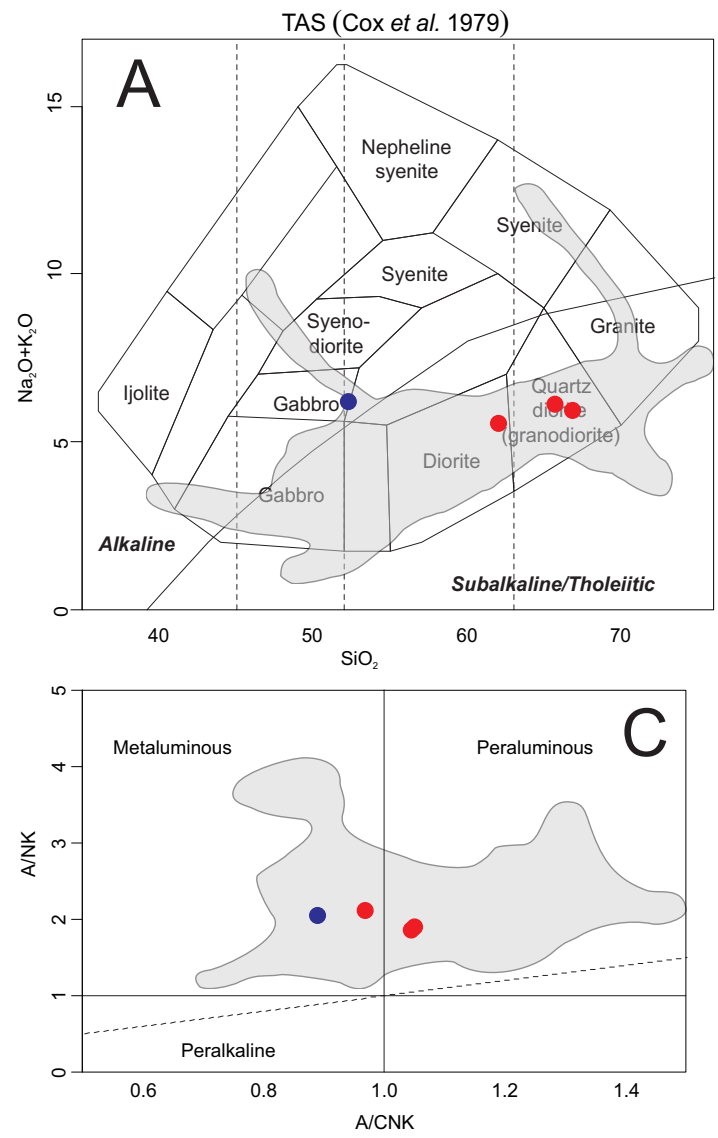

\subsubsection{Ovejas Batholith}

Four samples were analyzed for the Ovejas Batholith (AG 1.1, 1.2, 1.3 and 1.4) (Fig. 3). CLimages show mostly thin concentric overgrowths around an older core (Fig. 7). Although most of the analytical spots were located on zircons overgrowths, some of them were located on the cores (Fig. 7). Single-spot U-Pb ages obtained from the Ovejas Batholith samples yield ages between 85 and $66 \mathrm{Ma}$ (Fig. 7); meanwhile, intercept ages fall between 76.9 and $73.3 \mathrm{Ma}$ (Fig. 7). A weighted mean age calculated using those four ages yield an age of 75.2 $\mathrm{Ma}(\mathrm{MSWD}=0.47)$.

Although intercept ages from the Ovejas Batholith clearly define a coherent unique age for this magmatism, sample AG 1.1 has three zircons with ages $\sim 10$ M.y. younger (66-62 Ma) than the intercept age calculated for that sample. It is plausible that these zircons represent a later magmatic pulse

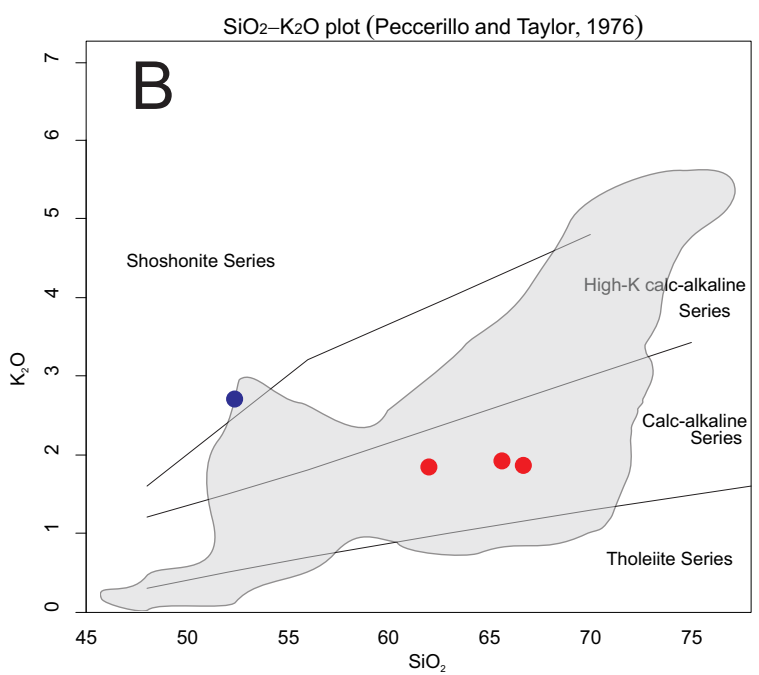

FIG. 4. Whole-rock classification and discrimination diagram from Ovejas main granitic mass (red dots) and enclave (blue dot). A. TAS based rock classification diagram (Cox et al. 1979); B. TAS discrimination diagram (Middlemost, 1994); C. Aluminum saturation index diagram (A/CNK versus A/NK (Shand, 1943).

which had affected part of the Ovejas Batholith between 66 and $64 \mathrm{Ma}$.

\section{Discussion}

\subsection{The length of the upper Cretaceous to Eocene arc magmatism in the Northern Andes and its tectonic setting}

Our new U-Pb crystallization ages from $\mathrm{La}$ Unión stock ( $c a .97 \mathrm{Ma}$ ) and Ovejas Batholith ( $c a .76$ to $73 \mathrm{Ma}$ ), together with ages previously reported for the Antioquia batholith and its satellite bodies (Ordóñez-Carmona et al., 2006; Correa et al., 2006; Restrepo-Moreno et al., 2007; Ibáñez-Mejía et al., 2007; Leal-Mejía, 2011; Villagómez et al., 2011) ranging from $\mathrm{ca}$. 89 to $58 \mathrm{Ma}$, suggest that after $\sim 20$ m.y. of magmatic quiescence, continental arc magmatism resumed during upper Cretaceous in 


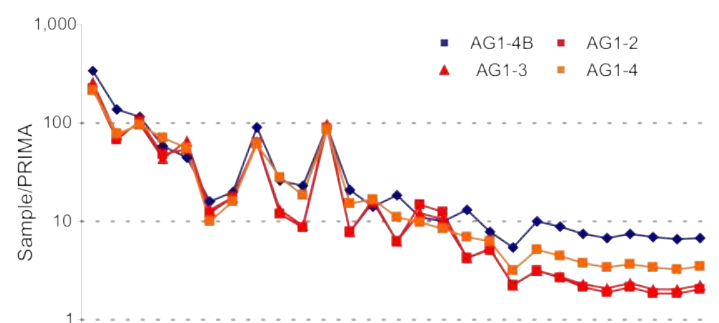

A

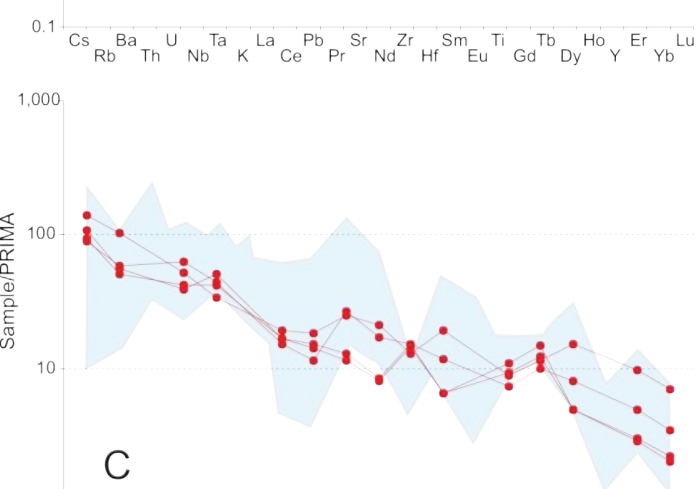

${ }^{1} \mathrm{Cs}_{\mathrm{Rb}}{ }^{\mathrm{Ba}} \mathrm{Th}_{\mathrm{K}} \mathrm{K}_{\mathrm{Na}}^{\mathrm{Ta}} \mathrm{Ce}^{\mathrm{Sr}} \mathrm{Nd}{ }^{\mathrm{P}} \mathrm{Hf}^{\mathrm{Zr}} \mathrm{Sm}{ }^{\mathrm{Ti}} \mathrm{Tb}^{\mathrm{Y}}$

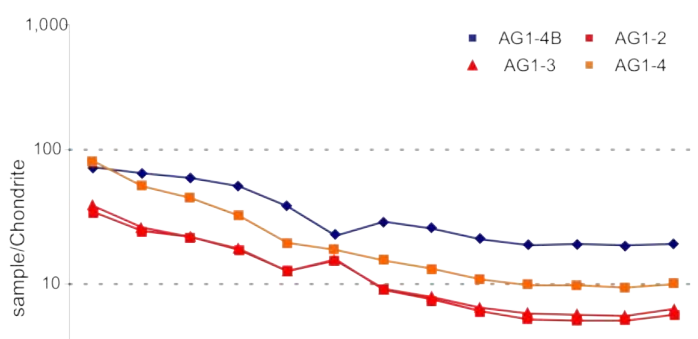

B
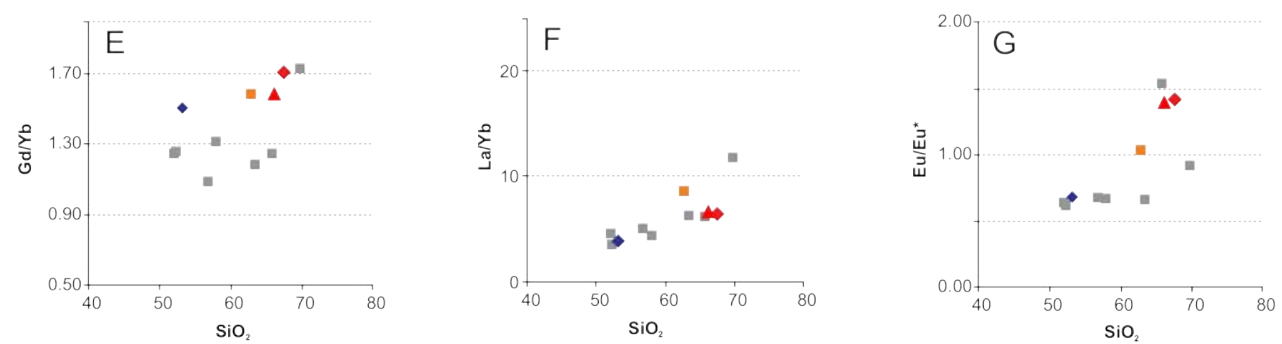

FIG. 5. Trace element diagrams for samples from ovejas Batholit (in red) and mafie enclave (in blue). A. Trace element (PRIMA normalized, Wood, 1979); B. REE normalized diagram (normalized using Boynton, 1984) spider-diagram from the Ovejas Batholith; C-D. Ovejas Batholith trace elements spider-diagrams compared with Leal-Mejía (2011); Antioquia Batholith data; E-G. Trace elements ratio for the Ovejas Batholith and Antioquia Batholith from Almeida and Villamizar (2012) in grey color.

TABLE 3. GEOCHRONOLOGICAL DATA FROM ANALYZED SAMPLES.

\begin{tabular}{ccccccc}
\hline Sample & Latitude & Longitude & m a.s.l. & $\begin{array}{c}\text { Age } \\
\text { (Ma) }\end{array}$ & $\begin{array}{c}\text { Error } \\
\text { (Ma) }\end{array}$ & $\begin{array}{c}\text { Inherited crystals } \\
\text { (Ma) }\end{array}$ \\
\hline Ovejas Batholith & & & & & & \\
AG 1.4 & $6.3252^{\circ}$ & $-75.5971^{\circ}$ & 2,343 & 74.3 & 1,9 & $92-86$ \\
AG 1.3 & $6.3316^{\circ}$ & $-75.5987^{\circ}$ & 2,400 & 76.9 & 2.5 & - \\
AG 1.2 & $6.3312^{\circ}$ & $-75.6018^{\circ}$ & 2,411 & 75.5 & 1 & - \\
AG 1.1 & $6.3488^{\circ}$ & $-75.6087^{\circ}$ & 2,479 & 73.3 & 2.4 & - \\
\hline La Unión Stock & & & & & & \\
AG 1.6 & $5.9770^{\circ}$ & $-75.3675^{\circ}$ & 2,493 & 97.2 & & \\
\hline
\end{tabular}



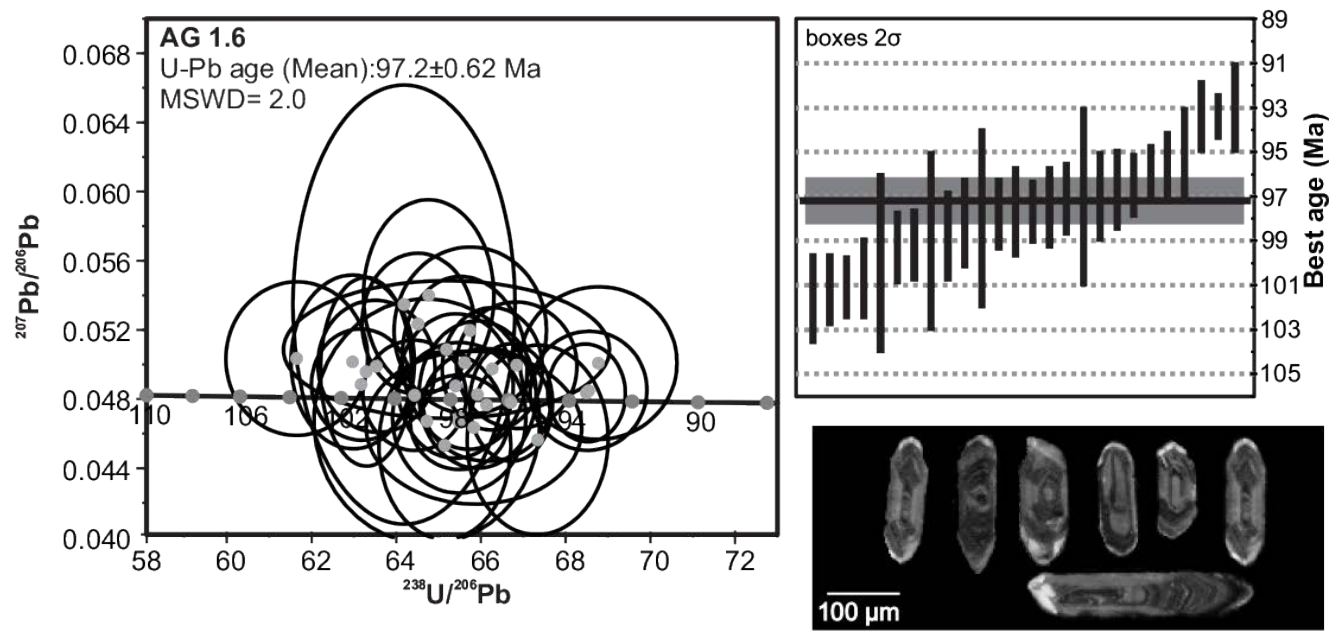

FIG. 6. U-Pb zircon (LA-ICP-MS) geochronology results from La Unión Pluton.

the Central Cordillera and lasted until the Eocene. Age distribution in the Antioquia batholith (Fig. 3) suggests that it was constructed from south to north, with a most voluminous period of magmatism between 89 and $72 \mathrm{Ma}$. However, despite the apparent 40 m.y. of continuous magmatism in the Central Cordillera, a clear gap between 72 and $63 \mathrm{Ma}$ is present as seen in figure $3 \mathrm{C}$ and in the detrital record ( $\mathrm{U}-\mathrm{Pb}$ in zircon) of sedimentary basins from eastern Colombia, where two group ages (Late Cretaceous and Paleogene) are abundant, whereas the $\sim 62$ to $70 \mathrm{~m} . \mathrm{y}$. ages are scarcely represented. It is noteworthy than the Antioquia Batholith is until now, the only vestige of late Cretaceous arc-related magmatism in the Central Cordillera. Conversely, the Paleogene magmatism is extended along the Central Cordillera (Bustamante et al., 2017) and the Caribbean region (Cardona et al., 2012, 2014).

According to such age distribution exposed over the present work, we propose to challenge previous geological models which suggest a southward magmatic migration during Paleogene (Ordóñez et al., 2001; Cardona et al., 2012; Pindell and Kennan, 2009; Pindell et al., 1998, 2006). Instead, we propose that continental arc magmatism was stationary during upper Cretaceous, forming the Antioquia Batholith, whereas its Paleogene pulse, $\sim 10 \mathrm{Ma}$ after the mentioned magmatic hiatus, was formed on the eastern side and share geochemical features with other Paleogene post-collisional plutons of the Central Cordillera (Bustamante et al., 2017). Further Miocene rotation of the Sierra Nevada de Santa Marta located northern of Colombia (Montes et al., 2010) and the oblique convergence between South America and the Caribbean Plate may have dispersed the Eocene granitoids from its former position (Cardona et al., 2014), which in turn, may explain the magmatic gap between the Central Cordillera and the Sierra Nevada de Santa Marta (Fig. 1). The coincidence of the aforementioned $\sim 10$ m.y. magmatic hiatus with increasing $\mathrm{Sr} / \mathrm{Y}$ ratios, suggest that the collision of the Caribbean plateau with NW South America may have caused such period of magmatic quiescence.

Whole rock geochemical results from the Ovejas Batholith indicate an arc related setting for this pluton according to the $\mathrm{Nb}$, Ti and Ta negative anomalies (Fig. 5) as well as the LREE/HREE ratios $\left([\mathrm{La} / \mathrm{Yb}]_{\mathrm{N}}\right.$ from 6.4 to 8.6). We compared our results with geochemical analyses obtained in previous works of the Antioquia Batholith (Botero, 1963; Feininger and Botero, 1982; González, 1980; Álvarez, 1983; Sáenz, et al., 2003; Villagómez, 2010; Almeida and Villamizar, 2012). Such compilation, however, lacks of the raw data and trace and REE analyses, and only eight of them are complete (Almeida and Villamizar, 2012). Analytical data obtained by Leal-Mejía (2011) are also included in this compilation by graphical comparison because the absence of the raw data.

Primordial mantle-normalized trace-element trends exhibit a clear enrichment in LILE over HFSE (Fig. 5A) with similar patterns as the obtained for the Ovejas Batholith. This can be compared in figure 5C 

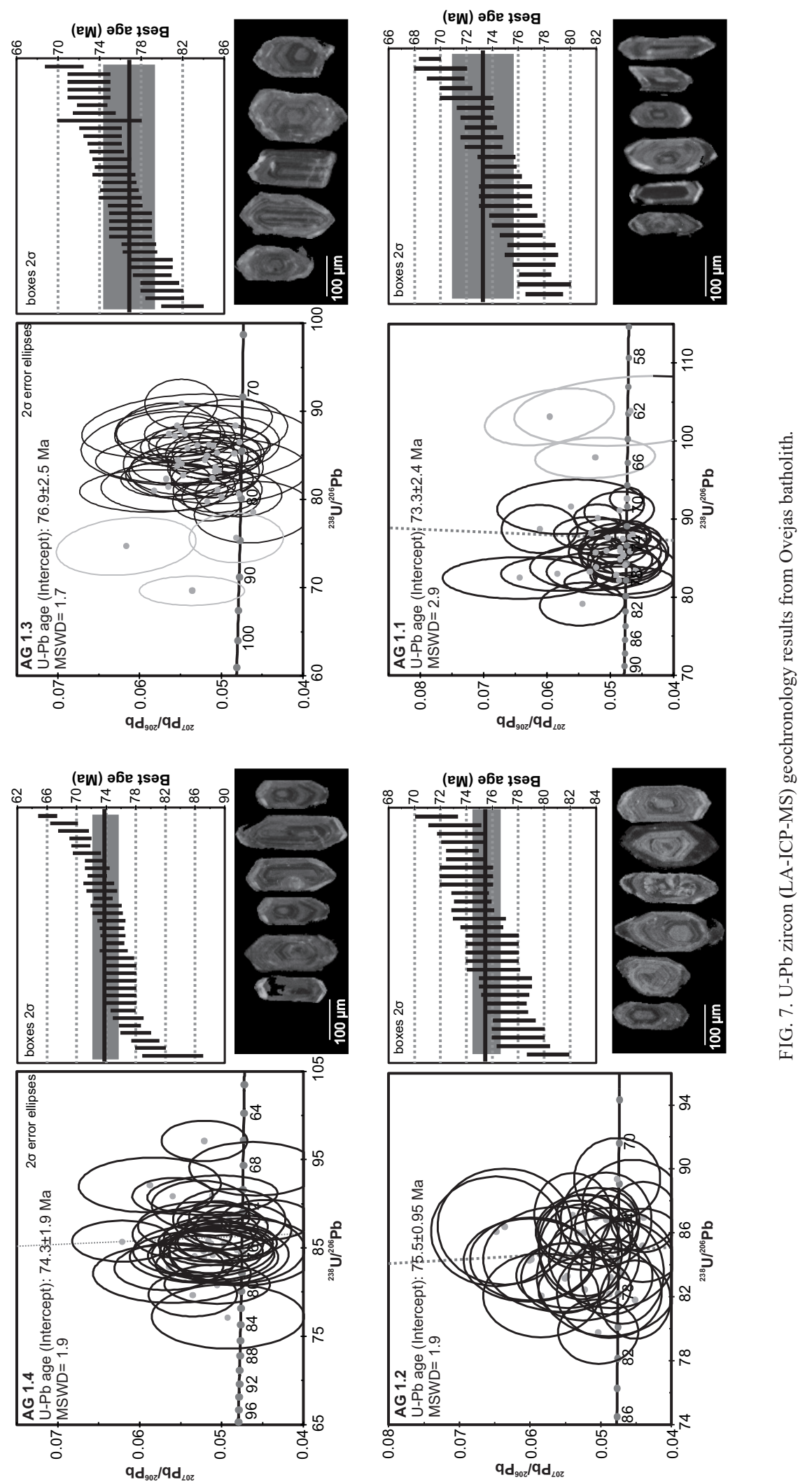
and by the $[\mathrm{La} / \mathrm{Yb}]_{\mathrm{N}}$ ratio values in figure $5 \mathrm{~F} . \mathrm{Nb}$, $\mathrm{Ta}$ and Ti negative anomalies, and $\mathrm{Zr}$, Hf positive anomalies are identifiable (Fig. 5A). Chondritenormalized REE patterns show enrichment in LREE versus HREE with similar patterns as those obtained for the Ovejas Batholith. Nevertheless, Antioquia batholith has less steep MREE-HREE patterns, indicated by the $\mathrm{Gd} / \mathrm{Yb}$ ratio.

Some authors consider these and other plutons in Aruba, Curaçao, Pujilí, Guajira, among others, as belonging to the tonalite-trondhjemite-granodiorite series or having an adakitic affinity (e.g., Wright and Wyld, 2011; Whattam and Stern, 2015). Pindell and Kennan (2009) consider that this series of plutons are so close to the Caribbean-South American Plate boundary and cast doubt on the normal arc setting for these rocks, suggesting the melting of a slabtip during subduction initiation. Conversely, we claim for a primitive continental arc setting for the Antioquia batholith and its satellite bodies based on the aforementioned geochemical evidences. Such magmatic arc is recording an increasing in its maturity with time as suggested in the $\mathrm{Rb} / \mathrm{Zr}$ versus $\mathrm{Nb}$ ratios (Fig. 8). Elliot et al. (1997) observed that incompatible elements like $\mathrm{Ba}$ and $\mathrm{Th}$ can be used as tracers of fluids derived from subducting slabs. In that sense, the high $\mathrm{Ba} / \mathrm{Th}(\sim 111$ to 185$)$ ratios of the Antioquia batholith are indicative of a continental arc where the slab derived fluids are increasing with maturity (Fig. 8). The stationary character of the magmatism represented by the Antioquia batholith, indicates that the subduction components (hydrous fluids) involved in the petrogenesis of these magmas would have changed locally, and are not related to the migration of the magmatic arc away from the trench.

\section{Conclusions}

Syn- to post-collisional tectonics characterized the NW margin of South America since the Late Cretaceous to the Eocene, mainly influenced by the interaction of the Farallón and Caribbean plates with this margin. The Antioquia batholith, built by successive magmatic pulses for $c a .40 \mathrm{~m}$.y., constitutes one of the main magmatic records of this tectonic scenario. Its crystallization history can be inferred according to new and already published U-Pb ages, whereas the whole rock geochemistry suggests that this magmatism is arc-related and that its locus may have been relatively stationary since no evidences of arc migration are recorded.

The latest magmatic phases of the Antioquia Batholith, Paleogene in age, constitute part of a magmatic arc that includes other small volume

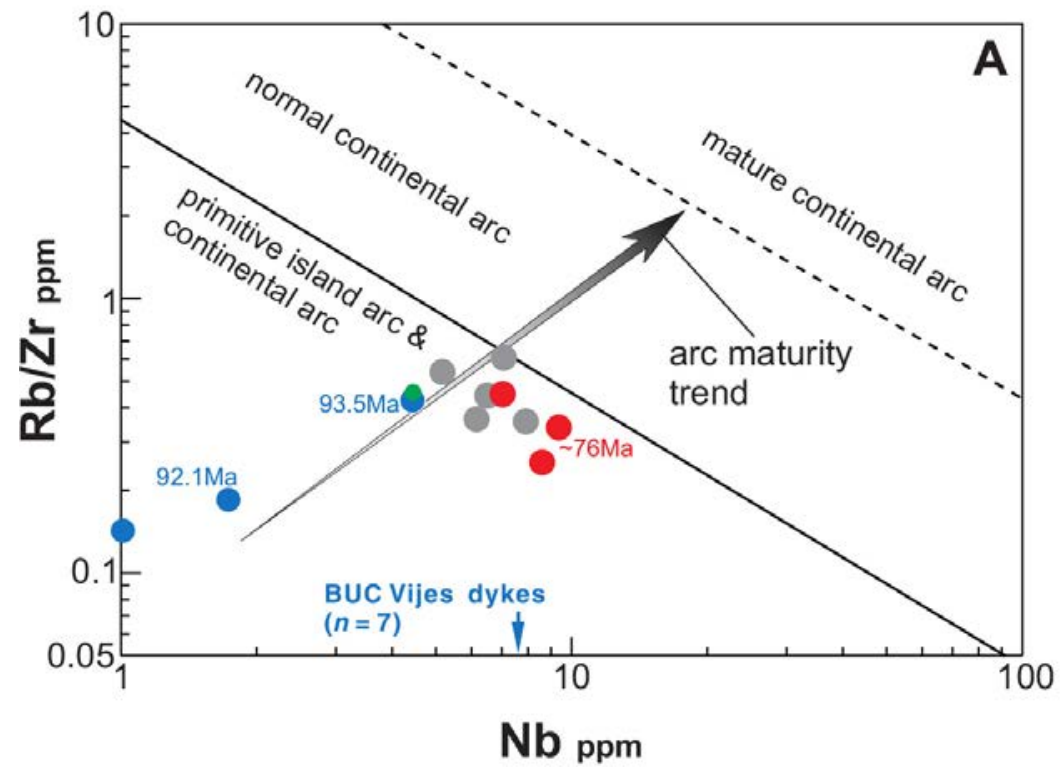

FIG. 8. Rb/Zr versus $\mathrm{Nb}$ diagram (Brown et al., 1984). Data from samples belonging to the Antioquia batholith from: Whatam and Stern (2015), blue dots; Almeida and Villamizar (2012), red dots; Villagómez (2010), green dots; this work, gray dots. 
plutons currently located at the Colombian Caribbean. This formerly arc would have been disrupted and dispersed by the interaction between the NW margin of South America and the Caribbean Plate which lead to rotation and translation of cortical blocks as well as basin formation.

\section{Aknowledgements}

The authors would like to thank C. Ortega Obregón and O. Pérez Arvizu from Laboratorio de Estudios Isotópicos (LEI) and J.T. Vázquez from CGEO, UNAM for their help during sample treatment. U. Cordani, A. Cardona and W. Vivallo are acknowledged for their constructive reviews that help to improve the manuscript.

\section{References}

Almeida, J.; Villamizar, F. 2012. Petrografía y geoquímica del Batolito Antioqueño en un sector del Municipio de Santa Rosa de Osos, Antioquia. Tesis de grado, Universidad Industrial de Santander: $216 \mathrm{p}$.

Álvarez, A. 1983. Geología de la Cordillera Central y el Occidente colombiano y petroquímica de los intrusivos granitoides Meso-Cenozóicos. Instituto Nacional de Investigaciones Geológico-Mineras 26 (2):1-175.

Andersen, T. 2002. Correction of common lead in U-Pb analyses that do not report ${ }^{204} \mathrm{~Pb}$. Chemical Geology 192 (1): 59-79.

Annen, C.; Blundy, J.D.; Leuthold, J.; Sparks, R.S.J. 2015. Construction and evolution of igneous bodies: Towards an integrated perspective of crustal magmatism. Lithos 230: 206-221.

Aspden, J.A.; McCourt, W.J.; Brook, M. 1987. Geometrical control of subduction-related magmatism: the Mesozoic and Cenozoic plutonic history of Western Colombia. Journal of the Geological Society 144 (6): 893-905.

Bayona, G.; Cardona, A.; Jaramillo, C.; Mora, A.; Montes, C.; Valencia, V.; Ayala, C.; Ibáñez-Mejía, M. 2012. Early Paleogene magmatism in the northern Andes: Insights on the effects of Oceanic Plateau-continent convergence. Earth and Planetary Science Letters 331: 97-111.

Best, M.G. 2013. Igneous and metamorphic petrology. John Wiley and Sons: $729 \mathrm{p}$.

Bissig, T.; Leal-Mejía, H.; Stevens, R.B.; Hart, C.J. 2017. High Sr/Y Magma Petrogenesis and the Link to Porphyry Mineralization as Revealed by GarnetBearing I-Type Granodiorite Porphyries of the Middle Cauca $\mathrm{Au}-\mathrm{Cu}$ Belt, Colombia. Economic Geology 112 (3): 551-568.
Blanco-Quintero, I.F.; García-Casco, A.; Toro, L.M.; Moreno, M.; Ruiz, E.C.; Vinasco, C.J.; Cardona, A.; Lázaro, C.; Morata, D. 2014. Late Jurassic terrane collision in the northwestern margin of Gondwana (Cajamarca Complex, eastern flank of the Central Cordillera, Colombia). International Geology Review 56 (15): 1852-1872.

Botero, G. 1963. Contribución al conocimiento de la zona central de Antioquia. Universidad Nacional de Colombia. Anales Facultad de Minas 57: 1-101. Medellín.

Botero, G.A.; González, H. 1983. Algunas localidades fosilíferas cretáceas de la Cordillera Central. Antioquia y Caldas, Colombia Norandina 7: 15-27.

Boynton, W.V.Z. 1984. Geochemistry of the rare earth elements: meteorite studies. Rare earth element geochemistry. Elsevier: 63-114.

Brown, G.C.; Thorpe, R.S.; Webb, P.C. 1984. The geochemical characteristics of granitoids in contrasting arcs and comments on magma sources. Journal of the Geological Society of London 141: 413-426.

Bustamante, C.; Archanjo, C.J.; Cardona, A.; Vervoort, J. D. 2016. Late Jurassic to Early Cretaceous plutonism in the Colombian Andes: A record of long-term arc maturity. Geological Society of America Bulletin 128 (11-12): 1762-1779.

Bustamante, C.; Cardona, A.; Archanjo, C.J.; Bayona, G.; Lara, M.; Valencia, V. 2017. Geochemistry and isotopic signatures of Paleogene plutonic and detrital rocks of the Northern Andes of Colombia: A record of post-collisional arc magmatism. Lithos 277: 199-209.

Caballero, V.; Mora, A.; Quintero, I.; Blanco, V.; Parra, M.; Rojas, L.E.; López, C.; Sánchez, N.; Horton, B.K.; Stockli, D.; Duddy, I. 2013. Tectonic controls on sedimentation in an intermontane hinterland basin adjacent to inversion structures: The Nuevo Mundo syncline, Middle Magdalena Valley, Colombia. Geological Society, Special Publications 377 (1): 315-342. London.

Cardona, A.; Valencia, V.; Bustamante, C.; García-Casco, A.; Ojeda, G.; Ruiz, J.; Saldarriaga, M.; Weber. M. 2010. Tectonomagmatic setting and provenance of the Santa Marta Schists, northern Colombia: Insights on the growth and approach of Cretaceous Caribbean oceanic terranes to the South American continent. Journal of South American Earth Sciences 29 (4): 784-804.

Cardona, A.; Valencia, V.A.; Bayona, G.; Duque, J.; Ducea, M.; Gehrels, G.; Jaramillo, C.; Montes, C.; Ojeda, G.;Ruiz, J. 2011. Early-subduction-related orogeny in the northern Andes: Turonian to Eocene 
magmatic and provenance record in the Santa Marta Massif and Rancheria Basin, northern Colombia. Terra Nova 23 (1): 26-34.

Cardona, A.; Montes, C.; Ayala, C.; Bustamante, C.; Hoyos, N.; Montenegro, O.; Ojeda, C.; Niño, H.; Ramírez V.; Valencia, V.; Rincón, D.; Vervoort, J.; Zapata, S. 2012. From arc-continent collision to continuous convergence, clues from Paleogene conglomerates along the southern Caribbean-South America plate boundary. Tectonophysics 580: 58-87.

Cardona, A.; Weber, M.; Valencia, V.; Bustamante, C.; Montes, C.; Cordani, U.; Muñoz, C. M. 2014. Geochronology and geochemistry of the Parashi granitoid, NE Colombia: Tectonic implication of short-lived Early Eocene plutonism along the SE Caribbean margin. Journal of South American Earth Sciences 50: 75-92.

Cochrane, R.; Spikings, R.; Gerdes, A.; Winkler, W.; Ulianov, A.; Mora, A.; Chiaradia, M. 2014. Distinguishing between in-situ and accretionary growth of continents along active margins. Lithos 202: 382-394.

Coleman, D.S.; Gray, W.; Glazner, A.F. 2004. Rethinking the emplacement and evolution of zoned plutons: Geochronologic evidence for incremental assembly of the Tuolumne Intrusive Suite, California. Geology 32 (5): 433-436.

Correa, M.; Pimentel, M.; Restrepo, J.J.; Nilson, A.; Ordoñez, O.; Martens, U.; Laux, U.; Junges, S. 2006. $\mathrm{U}-\mathrm{Pb}$ zircon ages and $\mathrm{Nd}-\mathrm{Sr}$ isotopes of the Altavista stock and the San Diego gabbro: New insights on Cretaceous arc magmatism in the Colombian Andes. In South American Symposium on Isotope Geology, No. 5: 84-86. Montevideo.

Cox, K.; Bell, J.; Pankhurst, R. 1979. The interpretation of igneous rocks. Allen and Unwin, London: $450 \mathrm{p}$.

Duque-Trujillo, J.; Ferrari, L.; Orozco-Esquivel, T.; LópezMartínez, M.; Lonsdale, P.; Bryan, S.E.; Kluesner, J.; Piñero-Lajas, D.; Solari, L. 2014. Timing of rifting in the southern Gulf of California and its conjugate margins: Insights from the plutonic record. Geological Society of America Bulletin 127 (5-6): 702-736. doi: 10.1130/B31008.1.

Elliot, T.; Plank, T.; Zindler, A.; White, W.; Bourdon, B. 1997. Element transport from slab to volcanic front at the Mariana arc. Journal of Geophysical Research 102: 14991-15019.

Feininger, T.; Botero, G. 1982. The Antioquian Batholith, Colombia. INGEOMINAS. Publicaciones Geológicas Especiales del INGEOMINAS 12: 1-150. Bogotá.
Fujiyoshi, A.; Ishizaka, K.; Hayase, I.; Tokuyama, A. 1976. Metamorphic and igneous rocks from MedellínYarumal and Santa Marta areas, Colombia and their $\mathrm{Rb} / \mathrm{Sr}$ ages. Journal of the Geological Society of Japan 82 (9): 559-563.

González, H. 1980. Geología de la planchas 167 (Sonsón) y 187 (Salamina) escala 1: 100.000. Boletín Geológico INGEOMINAS 23 (1): 1-174.

Ibáñez-Mejía, M.; Tassinari, C.C.G.; Jaramillo, J.M. 2007. U-Pb zircon ages of the "Antioquian Batholith": Geochronological constraints of late Cretaceous magmatism in the central Andes of Colombia. In Congreso Colombiano de Geología, No. 11. Abstract: 11 p. Paipa. Jaramillo, J.S.; Cardona, A.; Leon, S.; Valencia, V.; Vinasco, C. 2017. Geochemistry and geochronology from Cretaceous magmatic and sedimentary rocks at 6350 $\mathrm{N}$, western flank of the Central cordillera (Colombian Andes): Magmatic record of arc growth and collision. Journal of South American Earth Sciences 76: 460-481.

Kerr, A.C.; Tarney, J.; Marriner, G.F.; Nivia, A.; Saunders, A.D. 1997. The Caribbean-Colombian Cretaceous igneous province: the internal anatomy of an oceanic plateau. Large igneous provinces: Continental, oceanic, and planetary flood volcanism: 123-144.

Leal-Mejía, H. 2011. Phanerozoic Gold Metallogeny in the Colombian Andes: A Tectono-magmatic Approach: Ph.D. thesis (Unpublished), Universitat de Barcelona: $1000 \mathrm{p}$.

Lozano-Santa Cruz, R.; Verma, S.P.; Girón, P.; Velasco, F.; Morán, D.; Viera, F.; Chávez, G. 1995. Calibración preliminar de fluorescencia de rayos $\mathrm{X}$ para análisis cuantitativo de elementos mayores en rocas ígneas. Actas Instituto Nacional de Geoquímica 1: 203-208.

Ludwig, K.R. 2004. Isoplot/Ex: a geochronological toolkit for Microsoft Excel. Version 3. Berkeley, Berkeley Geochronology Center Publ. 4.

Martens, U.; Restrepo, J.J.; Ordóñez-Carmona, O.; CorreaMartínez, A.M. 2014. The Tahamí and Anacona terranes of the Colombian Andes: missing links between the South American and Mexican Gondwana margins. The Journal of Geology 122 (5): 507-530.

Middlemost, E. A. 1994. Naming materials in the magma/ igneous rock system. Earth-Science Reviews 37 (3-4): 215-224.

Montes, C.; Guzmán, G.; Bayona, G.; Cardona, A.; Valencia, V.; Jaramillo, C. 2010. Clockwise rotation of the Santa Marta massif and simultaneous Paleogene to Neogene deformation of the Plato-San Jorge and Cesar-Ranchería basins. Journal of South American Earth Sciences 29 (4): 832-848. 
Mora-Bohórquez, J.A.; Ibánez-Mejía, M.; Oncken, O.; de Freitas, M.; Vélez, V.; Mesa, A.; Serna, L. 2017. Structure and age of the Lower Magdalena Valley basin basement, northern Colombia: New reflectionseismic and $\mathrm{U}-\mathrm{Pb}-\mathrm{Hf}$ insights into the termination of the central andes against the Caribbean basin. Journal of South American Earth Sciences 74: 1-26.

Mori, L.; Gómez-Tuena, A.; Schaaf, P.; Goldstein, S.L.; Pérez-Arvizu, O.; SolÍs-Pichardo, G. 2009. Lithospheric removal as a trigger for flood basalt magmatism in the Trans-Mexican Volcanic Belt. Journal of petrology 50 (11): 2157-2186. doi: 10.1093/petrology/egp072.

Ordóñez-Carmona, O. 1997. O Pré-cambriano na parte norte da Cordilheira Central dos Andes colombianos. Tesis de maestría (Inédito), Universidad de Brasilia: 90 p.

Ordóñez-Carmona, O.; Pimentel, M. 2001. Consideraciones geocronológicas e isotópicas del Batolito Antioqueño. Revista de la Academia colombiana de ciencias exactas, físicas y naturales 25 (94-97): $27 \mathrm{p}$.

Ordóñez-Carmona, O.; Álvarez, J.J.R.; Pimentel, M.M. 2006. Geochronological and isotopical review of pre-Devonian crustal basement of the Colombian Andes. Journal of South American Earth Sciences 21 (4): 372-382.

Paton, C.; Woodhead, J.D.; Hellstrom, J.C.; Hergt, J.M.; Greig, A.; Maas, R. 2010. Improved laser ablation U-Pb zircon geochronology through robust downhole fractionation correction. Geochemistry, Geophysics, Geosystems 11 (3): Q0AA06. doi: 10.1029/2009GC002618.

Peccerillo, A.; Taylor, S.R. 1976. Geochemistry of Eocene calc-alkaline volcanic rocks from the Kastamonu area, northern Turkey. Contributions to mineralogy and petrology 58 (1): 63-81.

Pérez, G. 1967. Determinación de la edad de algunas rocas ígneas de Antioquia por el método K-Ar. Tesis de pregrado (Inédito), Universidad Nacional de Colombia: 46 p.

Pindell, J.L.; Kennan, L. 2009. Tectonic evolution of the Gulf of Mexico, Caribbean and northern South America in the mantle reference frame: an update. Geological Society, Special Publications 328 (1): 1-55. London.

Pindell, J.L.; Higgs, R.; Dewey, J.F. 1998. Cenozoic palinspastic reconstruction, paleogeographic evolution, and hydrocarbon setting of the northern margin of South America. In Paleogeographic Evolution and Non-Glacial Eustasy, Northern South America: SEPM (Pindell, J.L., Drake, C.L.; editors), Special Publication 58: 45-86.

Pindell, J.; Kennan, L.; Maresch, W.V.; Stanek, K.P.; Draper, G.; Higgs, R. 2005. Plate-kinematics and crustal dynamics of circum-Caribbean arc-continent interactions: Tectonic controls on basin development in Proto-Caribbean margins. Geological Society of America Special Papers 394: 7-52.

Pindell, J.L.; Kennan, L.; Stanek, K.P.; Maresch, W.V.; Draper, G.G. 2006. Foundations of Gulf of Mexico and Caribbean evolution: eight controversies resolved. Acta Geologica 4: 303-341.

Ramos, V.A. 2009. Anatomy and global context of the Andes: Main geologic features and the Andean orogenic cycle. Geological Society of America Memoirs 204: 31-65.

Ramos, V.A.; Aleman, A. 2000. Tectonic evolution of the Andes. Tectonic Evolution of South America 31: 635-685.

Restrepo-Moreno, S.A.; Foster, D.A.; Kamenov, G.D. 2007. Formation age and magma sources for the Antioqueño and Ovejas batholiths derived from $\mathrm{U}-\mathrm{Pb}$ dating and $\mathrm{Hf}$ isotope analysis of zircon grains. Geological Society of America Progr 39 (6).

Restrepo-Moreno, S.A.; Foster, D.A.; Stockli, D.F.; Parra-Sánchez, L.N. 2009. Long-term erosion and exhumation of the "Altiplano Antioqueño", Northern Andes (Colombia) from apatite (U-Th)/ He thermochronology. Earth and Planetary Science Letters 278 (1): 1-12.

Restrepo, J.J.; Ibáñez-Mejía, M.; García-Casco, A. 2012. $\mathrm{U}-\mathrm{Pb}$ zircon ages of the Medellin Amphibolites (Central Cordillera of Colombia) reveal mid-Cretaceous tectonic juxtaposition of Triassic and mid-Cretaceous metamorphic complexes. In Simposio Sudamericano de Geología Isotópica, No. 8, Medellín.

Restrepo, J.J. 1991. Datación de algunas cenizas volcánicas de Antioquia por el método de trazas de fisión. In Environmental Geology and Applied Geomorphology in Colombia (López Rendón, J.E.; editors). Universidad EAFIT, Association of Geoscientists for International Development Report 16: 148-1.

Restrepo, J.J.; Toussaint, J.F. 1990. Cenozoic arc magmatism of northwestern Colombia. Geological Society of America Special Papers 241: 205-212.

Sáenz, C.T.; Hackspacher, P.C.; Neto, J.H.; Iunes, P.J.; Guedes, S.; Ribeiro, L.F.B.; Paulo, S.R. 2003. Recognition of Cretaceous, Paleocene, and Neogene tectonic reactivation through apatite fission-track analysis in Precambrian areas of southeast Brazil: association with the opening of the South Atlantic Ocean. Journal of South American Earth Sciences 15 (7): 765-774.

Sáenz, E.A.; Paucar, C.G.; Restrepo, J.J. 1996. Estudio de la evolución térmica del Batolito Antioqueño por 
huellas de fisión. In Congreso Colombiano de Geología, No. 7, Memorias 2: 240-251. Bogotá.

Salazar, C.A.; Bustamante, C.; Archanjo, C.J. 2016. Magnetic fabric (AMS, AAR) of the Santa Marta batholith (northern Colombia) and the shear deformation along the Caribbean Plate margin. Journal of South American Earth Sciences 70: 55-68.

Sarmiento-Rojas, L.F.; Van Wess, J.D.; Cloetingh, S. 2006. Mesozoic transtensional basin history of the Eastern Cordillera, Colombian Andes: Inferences from tectonic models. Journal of South American Earth Sciences 21 (4): 383-411.

Shand, S.J. 1943. Eruptive rocks: their genesis, composition, classification, and their relation to ore deposits with a chapter on meteorites 552 (1): S43.

Sláma, J.; Košler, J.; Condon, D.J.; Crowley, J.L.; Gerdes, A.; Hanchar, J.M.; Horstwood, M.S.; Morris, G.A.; Nasdala, L.; Norberg, N.; Schaltegger, U. 2008. Plešovice zircon-a new natural reference material for $\mathrm{U}-\mathrm{Pb}$ and $\mathrm{Hf}$ isotopic microanalysis. Chemical Geology 249 (1): 1-35.

Solari, L.A.; Tanner, M. 2011. UPb. age, a fast data reduction script for LA-ICP-MS U-Pb geochronology. Revista Mexicana de Ciencias Geológicas 28 (1).

Solari, L.A.; Gómez-Tuena, A.; Bernal, J.P.; Pérez-Arvizu, O.; Tanner, M. 2010. U-Pb Zircon Geochronology with an Integrated LA-ICP-MS Microanalytical Workstation: Achievements in Precision and Accuracy. Geostandards and Geoanalytical Research 34 (1): 5-18.

Spikings, R.A.; Winkler, W.; Hughes, R.A.; Handler, R. 2005. Thermochronology of allochthonous terranes in Ecuador: Unravelling the accretionary and post-accretionary history of the Northern Andes. Tectonophysics 399 (1): 195-220.

Spikings, R.; Cochrane, R.; Villagomez, D.; Van der Lelij, R.; Vallejo, C.; Winkler, W.; Beate, B. 2015. The geological history of northwestern South America: From Pangaea to the early collision of the Caribbean large igneous province (290-75 Ma). Gondwana Research 27 (1): 95-139.

Toro, G.E.; Hermelin, M.; Schwabe, E.; Posada, B.; Silva, D.; Poupeau, G. 2006. Fission-track datings and geomorphic evidences for long-term stability in the
Central Cordillera highlands, Colombia. Zeitschrift für Geomorphologie, Supplementbände 145: 1-16.

Vallejo, C.; Winkler, W.; Spikings, R.A.; Luzieux, L.; Heller, F.; Bussy, F. 2009. Mode and timing of terrane accretion in the forearc of the Andes in Ecuador. Geological Society of America Memoirs 204: 197-216.

Villagómez, D. 2010. Thermochronology, geochronology and geochemistry of the Western and Central cordilleras and Sierra Nevada de Santa Marta, Colombia: The tectonic evolution of NW South America. Tesis de doctorado, Universidad de Ginebra: 143 p. Ginebra.

Villagómez, D.; Spikings, R. 2013. Thermochronology and tectonics of the Central and Western cordilleras of Colombia: Early Cretaceous-Tertiary evolution of the northern Andes. Lithos 160-161: 228-249.

Villagómez, D.; Spikings, R.; Magna, T.; Kammer, A.; Winkler, W.; Beltrán, A. 2011. Geochronology, geochemistry and tectonic evolution of the Western and Central cordilleras of Colombia. Lithos 125 (3-4): 875-896.

Villamil, T. 1999. Campanian-Miocene tectonostratigraphy, depocenter evolution and basin development of Colombia and western Venezuela. Palaeogeography, Palaeoclimatology, Palaeoecology 153 (1): 239-275.

Whattam, S.A.; Stern, R.J. 2015. Late Cretaceous plumeinduced subduction initiation along the southern margin of the Caribbean and NW South America: The first documented example with implications for the onset of plate tectonics. Gondwana Research 27 (1): 38-63.

Wood, D.A. 1979. A variably veined suboceanic upper mantle-genetic significance for mid-ocean ridge basalts from geochemical evidence. Geology 7 (10): 499-503.

Wright, J.E.; Wyld, S.J. 2011. Late Cretaceous subduction initiation on the eastern margin of the CaribbeanColombian Oceanic Plateau: One Great Arc of the Caribbean (?). Geosphere 7 (2): 468-493.

Zapata, J.; Correa, T.; Obando, M.; Rincón, A.; Ortiz, F.; Rodríguez, G. 2017. Redefinición cronoestratigráfica del Batolito de Sabanalarga. In Congreso Colombiano de Geología, No. 16 y Simposio de Exploradores, No. 3, Memorias: 1472-1477

Manuscript received: November 13, 2017; revised/accepted: July 19, 2018; available online: September 28, 2018. 